\title{
Drug-induced acid-base disorders
}

\author{
Daniel Kitterer • Matthias Schwab • M. Dominik \\ Alscher • Niko Braun • Joerg Latus
}

Received: 19 April 2014 /Revised: 28 August 2014 / Accepted: 3 September 2014 /Published online: 5 November 2014

(C) IPNA 2014

\begin{abstract}
The incidence of acid-base disorders (ABDs) is high, especially in hospitalized patients. ABDs are often indicators for severe systemic disorders. In everyday clinical practice, analysis of ABDs must be performed in a standardized manner. Highly sensitive diagnostic tools to distinguish the various ABDs include the anion gap and the serum osmolar gap. Drug-induced ABDs can be classified into five different categories in terms of their pathophysiology: (1) metabolic acidosis caused by acid overload, which may occur through accumulation of acids by endogenous (e.g., lactic acidosis by biguanides, propofol-related syndrome) or exogenous (e.g., glycol-dependant drugs, such as diazepam or salicylates) mechanisms or by decreased renal acid excretion (e.g., distal renal tubular acidosis by amphotericin $\mathrm{B}$, nonsteroidal antiinflammatory drugs, vitamin D); (2) base loss: proximal renal tubular acidosis by drugs (e.g., ifosfamide, aminoglycosides, carbonic anhydrase inhibitors, antiretrovirals, oxaliplatin or cisplatin) in the context of Fanconi syndrome; (3) alkalosis resulting from acid and/or chloride loss by renal (e.g., diuretics, penicillins, aminoglycosides) or extrarenal (e.g., laxative drugs) mechanisms; (4) exogenous bicarbonate loads: milk-alkali syndrome, overshoot alkalosis after bicarbonate therapy or citrate administration; and (5) respiratory acidosis or alkalosis resulting from drug-induced depression of the respiratory center or neuromuscular impairment (e.g., anesthetics, sedatives) or hyperventilation (e.g., salicylates, epinephrine, nicotine).
\end{abstract}

D. Kitterer $(\bowtie) \cdot$ M. D. Alscher $\cdot$ N. Braun $\cdot$ J. Latus Department of Internal Medicine, Division of Nephrology, Robert Bosch Hospital, Auerbachstr. 110, 70376 Stuttgart, Germany e-mail: daniel.kitterer@rbk.de

\section{Schwab}

Dr. Margarete Fischer-Bosch-Institute of Clinical Pharmacology, Stuttgart, Germany, and Department of Clinical Pharmacology, University Hospital, Tuebingen, Germany
Keywords Acid-base disorders · Drug-induced · Anion gap · Osmolar gap $\cdot$ Chloride depletion alkalosis

\section{Introduction}

Acid-base disorders (ABDs) are frequently present in hospitalized patients and are often a manifestation of systemic disorders. Analysis of ABDs must be performed in a standardized manner. Calculating the serum anion gap $(\mathrm{AG})$ is the first step to differentiate between ABDs [1-5]. The AG must be corrected for serum albumin levels, and it must be considered that several factors (e.g., paraproteinemia, lithium, and bromide intoxication; hypercalcemia; hypermagnesemia; syndrome of inappropriate antidiuretic hormone secretion (SIADH); severe hyperphosphatemia), as well as the laboratory measurement method used [1], could interfere with the calculation. Clinical information, including medical history and laboratory data, must be obtained from the patient, especially in differentiating possible mixed acid-base disturbances. The urine $\mathrm{AG}$ (UAG) is a useful tool for differentiating ABDs, especially in patients with metabolic acidosis with normal serum AG. UAG can be used as a parameter for acid excretion by the kidney: ([urine sodium ions $\left.\left(\mathrm{Na}^{+}\right)\right]+[$urine potassium ions $\left.\left(\mathrm{K}^{+}\right)\right]$) - [urine chloride $\left.\left(\mathrm{Cl}^{-}\right)\right]$), normal range -10 to + $10 \mathrm{mmol} / \mathrm{L}$ ). A negative UAG (average $\geq 15 \mathrm{mmol} / \mathrm{l}$ ) indicates an increased ammonium $\left(\mathrm{NH}_{4}{ }^{+}\right)$excretion (e.g., diarrhea) in metabolic acidosis with normal serum AG. In such cases, positive UAG $(>20 \mathrm{mmol} / \mathrm{l})$ indicates a low urinary $\mathrm{NH}_{4}{ }^{+}$ excretion [altered distal urinary acidification, e.g., altered renal tubular acidosis (RTA)]. It should be noted that UAG is influenced by exogenous anions (ketonuria, penicillins, and high doses of acetylsalicylic acid). In patients with positive UAG, determining urine $\mathrm{pH}$ could help distinguish between the different types of RTA: type 1 is characterized by a fixed urine $\mathrm{pH}$ of $>5.5$ and decreased or normal serum $\mathrm{K}^{+}$levels; 
type 2 by urine $\mathrm{pH}$ levels $<5.5$; and type 4 commonly by hyperkalemia and urine $\mathrm{pH}$ levels $<5.5$ (Fig. 1).

The AG can be calculated using the simplified formula $\left[\mathrm{Na}^{+}\right]-\left(\left[\mathrm{Cl}^{-}\right]+\left[\right.\right.$bicarbonate $\left.\left.\left(\mathrm{HCO}_{3}{ }^{-}\right)\right]\right)$(normal range, 3$11 \mathrm{mEq} / \mathrm{L}$ ), measured with ion-selective electrodes, up to $18 \mathrm{mEq} / \mathrm{L}$ in newborns; if serum $\mathrm{K}^{+}$is included in $\mathrm{AG}$ measurement, normal range is $\sim 4 \mathrm{mEq} / \mathrm{L}$ higher $[1,6-9]$. It is noteworthy that the AG depends on plasma albumin levels, and hypoalbuminemia is a common finding in hospitalized patients. A decrease of $1.0 \mathrm{~g} / \mathrm{dl}$ (from $4.5 \mathrm{~g} / \mathrm{dl}$ ) of albumin concentration decreases the $\mathrm{AG}$ by roughly $2.5 \mathrm{mEq} / \mathrm{L}$ [10-12]. Increased AG indicates acid overload caused by ketoacidosis, lactic acidosis, uremia, salicylates, methanol, or ethylene glycol intoxication. If there is an increased $A G$, the osmolar gap (OG), defined as the difference between measured and calculated serum osmolality, should be calculated to detect methanol or ethylene glycol intoxication, which will result in an increased OG ([2 Na+glucose $] / 18)+($ blood urea nitrogen [BUN/2.81]); correction factors for calculating the $\mathrm{OG}$ are only required in if nonstandard units (i.e., $\mathrm{mg} / \mathrm{dl}$ ) are used. However, simple alcohol (ethanol) intoxication with lactate acidosis can resemble changes [13]. The normal OG range is wide in children (from +8.9 to $-13.5 \mathrm{mOsm} / \mathrm{L}$ ), but intoxication must be considered when the $\mathrm{OG}$ is positive $(>10 \mathrm{mOsm})$ [14]. Furthermore, in high-AG metabolic acidosis, the change in AG should correlate with the change in serum $\mathrm{HCO}_{3}{ }^{-}$concentration. A further hint to the presence of mixed metabolic $\mathrm{ABD}$ is the relationship between the increase in $\mathrm{AG}(\triangle \mathrm{AG})$ and decrease in $\mathrm{HCO}_{3}^{-}\left(\Delta \mathrm{HCO}_{3}\right)$. It has been suggested that mixed ABD should be considered if the $\triangle \mathrm{AG} /$ $\Delta \mathrm{HCO}_{3}{ }^{-}$ratio is $<0.8$ or $>1.2$ [15-17]. Additionally, calculating the UAG could be useful to differentiate ABDs. A negative UAG indicates increased $\mathrm{NH}_{4}{ }^{+}$excretion (e.g., diarrhea) of the kidney. In metabolic acidosis without elevated AG, positive UAG is associated with low urinary $\mathrm{NH}_{4}^{+}$(e.g., RTA) [18-20].

Drug-induced ABDs (DABDs) are very common in everyday clinical practice. Renal clearance of the drug and/or its metabolite(s) is an important mechanism of drug elimination. Renal drug clearance can be reduced in patients with acute and chronic kidney injury, and the drug and/or its metabolites can cause tubular necrosis or interstitial nephritis. In this review, we focus on direct drug-induced effects on the proximal tubule cell, the thick ascending limb cell, the collecting duct principal cell and the collecting duct intercalated cell. Mechanisms of acute kidney failure due to tubular necrosis and interstitial nephritis caused by antibiotics are beyond the scope of this review and are reviewed elsewhere [21, 22]. First, we give a short summary of the pathophysiology of the different disorders of acid-base homeostasis based on the different findings in analysis of arterial or, if not available, venous blood gases, which is usually the first diagnostic step in everyday clinical practice (Fig. 1). Second, we go into detail about the selected drugs and their potential to cause ABDs, especially in children.

\section{Metabolic acidosis}

Increased acid production (normochloremic metabolic acidosis with elevated anion gap)

\section{Pathophysiology}

In metabolic acidosis with increased acid production, the arterial partial pressure of carbon dioxide $\left(\mathrm{pCO}_{2}\right)$ is appropriately decreased because of respiratory compensation. Furthermore, increased acid production leads to a decrease in $\mathrm{HCO}_{3}$. In patients without appropriately decreased $\mathrm{pCO}_{2}$, an additional respiratory acidosis must be considered. If $\mathrm{pCO}_{2}$ is lower as expected, a further respiratory alkalosis might be present. Next step, AG must be calculated to detect addition of acids (Fig. 1) and must be adjusted for serum albumin levels. In patients with otherwise (e.g., lactic acidosis, uremia, or ketoacidosis), unexplained high-AG metabolic acidosis, the serum OG should be calculated. In patients with elevated $A G$ and high OG intoxication of methanol, ethylene glycol or ingestion of propylene-glycol-containing drugs must be considered. However, it should be noted that ethanol itself leads to an elevated OG without resulting necessarily in metabolic acidosis. Furthermore, severe ethanol ingestion might cause ketoacidosis. Other considerations in regard to normochloremic metabolic acidosis with elevated AG are drugs such as linezolid, propofol infusion syndrome (PRIS), metforminassociated lactic acidosis (MALA), and-rarely—penicillins (Table 1).

Linezolid Linezolid is the first member of the oxazolidinone drug family. The efficacy of linezolid in children is similar to those of vancomycin and cefadroxil. The most common side effects are diarrhea, nausea, vomiting, and thrombocytopenia. Linezolid is used in children to treat infections, mainly those caused by resistant Gram-positive organisms or drug-resistant tuberculosis [23-26]. Linezolid can cause lactic acidosis in a small proportion of patients [27]. The risk for linezolidinduced lactic acidosis is associated with duration of therapy [28], but early linezolid-induced lactic acidosis has also been reported [29]. Some studies using cell-culture experiments have suggested that linezolid toxicity is caused by inhibition of mitochondrial protein synthesis [30-32]. There is some evidence that polymorphisms in the mitochondrial $16 \mathrm{~S}$ ribosomal RNA (rRNA) (e.g., A1036G) may contribute to severe linezolid-associated lactic acidosis in adults [33, 34]. The prognosis of linezolid-induced lactic acidosis is unclear; in some cases, the outcome was excellent, but there are also some reports of patients with fatal outcome [28, 35]. 
1.

2.
A.
B.

\begin{tabular}{|l|}
\hline $\begin{array}{l}\text { L-Lactate } \\
\text { acidosis }\end{array}$ \\
\hline
\end{tabular}
C.
Kidney failure
D. Intoxication

$\begin{array}{ll}\begin{array}{l}\text { Osmolar gap present } \\ \text { (OG }>10 \text { mOsm) }\end{array} & \begin{array}{l}\text { Osmolar gap absent } \\ (\mathbf{O G}<\mathbf{1 0} \text { mOsm) }\end{array} \\ \text { - Methanol } & \text { - Salicylates } \\ \text { - Ethylene glycol } & \text { - Paraldehyde } \\ \text { - Ketoacidosis } & \\ \text { - Uremia } & \\ \text { - Lactic acidosis } & \end{array}$

Leading causes of hyperchloremic metabolic acidosis with normal AG :
A. GI loss of $\mathrm{HCO}_{-}$-
B. Renal tubular acidosis
C.

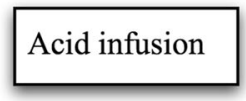
D. Recovery phase of ketoacidosis
4. Assessment of the compensatory
Decrease or increase of $\mathrm{pCO} 2$ and $\mathrm{HCO} 3-$
5. Comparison of $\Delta \mathrm{AG}$ and $\Delta \mathrm{HCO} 3-$
$\Delta \mathrm{AG} / \Delta \mathrm{HCO} 3$ ratio $<0.8$ or $>1.2$
Mixed ABD ?
6. Comparison of electrolyte balance alterations with suspected ABD (e.g. urinary anion gap $\left[\left(\left[\mathrm{UrineNa}^{+}\right]+\right.\right.$
$[\mathrm{UrineK}+])-[\mathrm{UrineCl}]]$, urinary electrolytes)
7. Additional urine analysis

\section{using urine electrolyte excretion and assement of volume state}
8. Analyses of metabolic alkalosis
Acute respiratory compensation in metabolic acidosis :
- Decrease of pCO2 (from $40 \mathrm{mmHg}$ ) correspond to the decrease of $\mathrm{HCO} 3$ - (from $24 \mathrm{mmol} / \mathrm{l}$ )
Chronical metabolic compensation in respiratory acidosis:
- Increase of $0.3 \mathrm{mmol} / 1 \mathrm{HCO} 3$ - per $1 \mathrm{mmHg}$
decrease in $\mathrm{pCO} 2$

\section{$\Delta \mathrm{AG} / \Delta \mathrm{HCO3}$ ratio $<0.8$ :}
- Ketoacidosis, D-lactic acidosis, or toluene intoxication, serum AG may be normal $\triangle \mathrm{AG} / \triangle \mathrm{HCO}$ ratio $<1.2$ :
- Mixed ABD serum $\mathrm{HCO} 3$ - concentration is
higher as expected based upon the large serum AG
Consider additional urinary AG in acidosis with normal serum $A G$ :
- Urine AG $(>-15 \mathrm{mmol} / \mathrm{l})$
- GI loss of bicarbonate - proximal RTA $(\mathrm{fK}+\mathrm{e}=\mathrm{N}$ or $\mathrm{I})$
$+\quad$ Urine AG (>20 mmol/l)
- presence of altered distal urinaryacidification (e.g. RTA)
Urine-pH $>5.5$ RTA type I $(\mathrm{fK}+\mathrm{e}=\mathrm{I})$ Urine-pH $>5.5$ RTA type II, increase by $\mathrm{HCO} 3$ - infusion $(\mathrm{fK}+\mathrm{e}=\mathrm{D})$

\section{A. EABV decreased}
B. EABV increased or normal

$\downarrow$ Urine $\mathrm{Cl}-<\mathbf{2 0} \mathbf{~ m E q} / \mathrm{l}$
Urine $\mathrm{Cl}->20 \mathrm{meq} / \mathrm{l}$ $\downarrow$ Urine $\mathrm{Na}+$

- Posthypercapneic (often in patients with mechanical ventilation and decreased EABV)

- Remote use of diuretics (CDA)

- Loss of $\mathrm{NaCl}$ via GI tract
- Chloride loss by active vomiting or nasogastric suction

- Excretion of non-reabsorbable anion (urine $\mathrm{pH}<6.5$ ), e.g. Penicillins
- Current diuretic use - Bartter's-like syndromes 
Fig. 1 Standardized approach for analyzing disturbances in acid-base physiology. $\mathrm{AG}$ anion gap, $\mathrm{HCO}_{3}{ }^{-}$bicarbonate, $\mathrm{K}^{+}$potassium ions, $\mathrm{Na}^{+}$ sodium ions, $C \Gamma$ chloride ions, $B U N$ blood urea nitrogen, $A B D$ acid-base disorders, $G I$ gastrointestinal tract, $E A B V$ effective arterial blood volume, $C D A$ chloride depletion alkalosis, $R T A$ renal tubular acidosis, $f K^{+} \mathrm{e}$ fractional $\mathrm{K}^{+}$excretion, $N$ normal, $I$ increased, $D$ decreased

Propofol infusion syndrome Propofol is a short-acting intravenously administered anesthetic agent widely used in both adults and children for sedation or anesthesia [36, 37]. PRIS is a rare complication, which is associated with high doses ( $>4 \mathrm{mg} / \mathrm{kg} / \mathrm{h}$ ) and long-term use ( $>48 \mathrm{~h}$ ) of propofol, concomitant steroid therapy, high consumption of vasopressors, and patient age $<18$ years $[38,39]$. The incidence of PRIS is $\sim 1 \%$ in adult patients [40]. There are no valid data for children, but propofol use in children in pediatric intensive care units (PICUs) appeared to be safe when doses did not exceed $4 \mathrm{mg} / \mathrm{kg} / \mathrm{h}$ and use was restricted to $<24 \mathrm{~h}[41,42]$. Patients should be monitored closely for the presence of elevated triglycerides and lactic acidosis [43]. PRIS leads to characteristic symptoms and clinical signs, including hepatomegaly, severe metabolic acidosis, rhabdomyolysis, hyperkalemia, acute kidney injury, dyslipidemia, and progressive myocardial failure with dysrhythmias [44]. Most patients with PRIS present with severe metabolic acidosis with elevated lactate levels and metabolic alkalosis. Elevated lactate levels in patients receiving propofol infusion, which cannot be explained otherwise, might be an early marker of PRIS [45]. There is experimental evidence that in states of increased metabolic demand with reduced glycogen reserves and increased fattyacid oxidation, propofol affects mitochondrial fatty-acid

Table 1 Acid-base disturbances caused by drugs

\begin{tabular}{|c|c|c|}
\hline Clinical disturbance and relevant drugs & Frequency & Mechanism \\
\hline \multicolumn{3}{|c|}{ Normochloremic metabolic acidosis with elevated AG } \\
\hline Linezolid & Rare & Mitochondrial toxicity \\
\hline IV drugs containing propylene glycol & Rare & Glycolic and oxalic acid accumulation \\
\hline Propofol infusion syndrome (PRIS) & Rare & Mitochondrial toxicity \\
\hline Biguanide & Rare & Mitochondrial toxicity \\
\hline Penicillins & Rare & Disturbance of the gamma glutamyl cycle \\
\hline \multicolumn{3}{|c|}{ Hyperchloremic metabolic acidosis with normal AG } \\
\hline NSAIDs, heparin, LMWH & Rare & Mineralocorticoid deficiency with RTA type 4 \\
\hline Spironolactone, eplerenone, & Frequent & Inhibition of the $\mathrm{Na}^{+}$reabsorption $(\mathrm{ENaC})$ \\
\hline Amiloride, triamterene & Frequent & Inhibition of the $\mathrm{Na}^{+}$reabsorption $(\mathrm{ENaC})$ \\
\hline Trimethoprim & Rare & Inhibition of the $\mathrm{Na}^{+}$reabsorption $(\mathrm{ENaC})$ \\
\hline Pentamidine & Rare & Inhibition of the $\mathrm{Na}^{+}$reabsorption $(\mathrm{ENaC})$ \\
\hline Amphotericin B & Rare & $\begin{array}{l}\text { RTA type } 1 \text { with hypokalemia by increasing membrane permeability in the collecting } \\
\text { duct }\end{array}$ \\
\hline Foscarnet & Rare & Mitochondrial dysfunction \\
\hline Ifosfamide & Frequent & CAA toxicity with Fanconi syndrome \\
\hline Oxaliplatin and cisplatin & Rare & Fanconi syndrome \\
\hline Acetazolamide (CA) & Frequent & Inhibition of CA IV \\
\hline Antiretrovirals & Rare & Mitochondrial toxicity \\
\hline Valproic acid & Rare & Unclear \\
\hline Aminoglycosides & Rare & Fanconi syndrome \\
\hline Tetracyclines & Rare & Fanconi syndrome \\
\hline \multicolumn{3}{|l|}{ CDA } \\
\hline Loop diuretics & Frequent & $\mathrm{CDA}$ \\
\hline Thiazide diuretics & Rare & $\mathrm{CDA}$ \\
\hline Penicillins & Frequent & Nonreabsorbable anion \\
\hline Aminoglycosides & Frequent & Bartter-like syndrome by CaSR stimulation \\
\hline \multicolumn{3}{|l|}{ Non-CDA } \\
\hline $\begin{array}{l}\text { Calcium-alkali syndrome (milk-alkali } \\
\text { syndrome) }\end{array}$ & Rare & Activation of the CaSR \\
\hline
\end{tabular}

$\mathrm{Na}^{+}$sodium ion, $E N a C$ epithelial sodium channel, $R T A$ renal tubular acidosis, $C A A$ chloroacetaldehyde, $C A$ carbonic anhydrase, $C D A$ chloride depletion alkalosis, CaSR calcium-sensing receptor 
oxidation, leading to PRIS, and inhibits the level of mitochondrial oxidative phosphorylation and lipid metabolism [46, 47].

Drugs containing glycols Propylene glycol (PG) is a watersoluble alcohol that serves as a solvent in a variety of intravenously administered drugs. Physicochemically, it is similar to ethylene glycol but less toxic [48]. PG toxicity is typically characterized by acidosis, increased AG and/or OG, hypernatremia, or hepatic dysfunction, with increase in direct serum bilirubin and acute kidney injury [49]. There is a variety of drugs containing PG (Table 2). For example, lorazepam and diazepam IV are widely used drugs containing PG [50]. The incidence of PG toxicity is still unknown. Severity of PG toxicity ranges from common metabolic abnormalities to infrequent cases of clinical deterioration with systemic inflammatory response syndrome (SIRS) [51]. High-dose application of benzodiazepine in patients with impaired kidney function appears to be a risk factor for PG toxicity [52]. The incidence of PG toxicity in children is unknown. Critically ill neonates receiving medications by continuous infusions are at higher risk of being exposed to PG. However, a median PG exposure of $34 \mathrm{mg} / \mathrm{kg}$ per $24 \mathrm{~h}$ seems to be well tolerated [53-55]. Treatment of toxicity includes termination of any PG-containing medication and initiation of hemodialysis in severe cases to effectively remove PG [49]. Although PG is metabolized by alcohol dehydrogenase (ADH), such as ethanol, methanol, and ethylene glycol, there is no evidence for fomepizole as an inhibitor of ADH in PG toxicity [56].

Biguanide The biguanide hypoglycemic agents phenformin and metformin became available for clinical use in the 1950s, and metformin is still considered the first choice for treatment of type 2 diabetes (T2D). In December 2000, the US Food and Drug Administration (FDA) approved the use of metformin for children with T2D. Studies have not been conducted in children younger than 10 years of age $[57,58]$. MALA is a possible side effect, but it seems to be a rare event. Recently, a Cochrane Review demonstrated a low incidence for MALA in adult patients with type 2 diabetes receiving metformin in the context of clinical studies. Poisson statistics reported 5.1 cases per 100,000 patient-years $[59,60]$. There is some evidence that high doses of metformin lead to MALA, especially in patients with impaired kidney function [61, 62]. No large, prospective, randomized trials of metformin have been carried out in children. In 2000, a multicenter case series in a pediatric patient cohort reported no evidence of lactic acidosis (median dose of metformin was $1,700 \mathrm{mg}$ ) [63]. The pathophysiology of MALA is complex and not fully understood. Studies on rat liver mitochondria hypothesized that metformin inhibits mitochondrial oxidation, leading to inhibition of respiratory chain function [64, 65]. In addition, metformin inhibits hepatic gluconeogenesis, possibly via a decrease in the cytosolic adenosine triphosphate/adenosine diphosphate (ATP/ADP)
Table 2 Frequently used intravenously administered drugs containing varying amounts of propylene glycol

\begin{tabular}{ll}
\hline Drug & $\begin{array}{l}\text { Propylene glycol (\% vol/ } \\
\text { vol) }\end{array}$ \\
\hline Lorazepam, $2 \mathrm{mg} / \mathrm{ml}$ & 80 \\
Diazepam, $5 \mathrm{mg} / \mathrm{ml}$ & 40 \\
Phenobarbital, $30-130 \mathrm{mg} / \mathrm{ml}$ & $68-75$ \\
Phenytoin, $50 \mathrm{mg} / \mathrm{ml}$ & 40 \\
Trimethoprim-sulfamethoxazole, (16:80) & 40 \\
$\quad$ mg/ml & 35 \\
Etomidate, $2 \mathrm{mg} / \mathrm{ml}$ & 30 \\
Nitroglycerin, $5 \mathrm{mg} / \mathrm{ml}$ & 25 \\
Esmolol, $250 \mathrm{mg} / \mathrm{ml}$ &
\end{tabular}

Adapted from [184], with permission

ratio, resulting in reduced utilization of lactate [66]. In critically ill patients with MALA and severe metabolic acidosis ( $\mathrm{pH}<7.1$ ), hemodialysis should be considered [67].

Penicillins Rarely, penicillins may cause a disturbance in the gamma glutamyl cycle, with decreased 5-oxoproline and pyroglutamate, analogous to acetaminophen, causing metabolic acidosis with elevated AG [68-70].

\section{Decreased renal acid excretion (hyperchloremic metabolic acidosis with normal anion gap)}

Pathophysiology

Hyperchloremic metabolic acidosis with normal AG could be caused by loss of $\mathrm{HCO}_{3}{ }^{-}$via the gastrointestinal (GI) tract or hydrochloric acid ingestion. Furthermore, an altered distal urinary acidification of the kidney (RTA type 1 ) or impairment of $\mathrm{HCO}_{3}{ }^{-}$reabsorption in the proximal tubule, which results in decreased renal $\mathrm{HCO}_{3}{ }^{-}$threshold (RTA type 2), can occur. Other common causes for hyperchloremic metabolic acidosis with normal AG include mineralocorticoid deficiency or a reduced $\mathrm{NH}_{4}^{+}$excretion in the context of impaired glomerular filtration rate (GFR). Rarely, decreased $\mathrm{NH}_{4}{ }^{+}$excretion causing disturbances of aminogenesis (glutamine metabolism) might lead to hyperchloremic metabolic acidosis with normal AG.

In patients with hyperchloremic metabolic acidosis with normal serum AG, analyses of the urine serum gap can help distinguish between gastrointestinal loss of $\mathrm{HCO}_{3}{ }^{-}$and the presence of altered distal urinary acidification or $\mathrm{HCO}_{3}{ }^{-}$ wasting (e.g., RTA) (Fig. 1). Aldosterone deficiency, antagonisms, or resistance might lead to loss of function of the epithelial sodium channel (ENaC) (Fig. 3). ENaC inhibition might result in hyperkalemia, which raises intracellular $\mathrm{pH}$ 
and could interfere with enzymes involved in aminogenesis, leading to decreased $\mathrm{NH}_{4}^{+}$excretion. Reduced $\mathrm{NH}_{4}^{+}$excretion might lead to impaired hydeogen ion $\left(\mathrm{H}^{+}\right)$secretion, with hyperkalemic RTA (type 4 distal RTA) [71, 72].

Angiotensin-converting enzyme (ACE) and angiotensin II receptor antagonists (AT2RA) decrease $\mathrm{Na}^{+}$reabsorption and could induce hyperkalemic RTA via the aldosterone axis. Furthermore, drugs interfering with $\mathrm{Na}^{+}$- channel function can cause hyperkalemic RTA due to decreased distal $\mathrm{H}^{+}$ secretion.

\section{Inhibition of the aldosterone axis (angiotensin inhibition and heparin-induced selective aldosterone deficiency)}

Aldosterone deficiency or antagonism with renal tubular acidosis type 4 (mineralocorticoid deficiency)

Renin inhibition can be triggered by simultaneous use of cyclooxygenase inhibitors (nonsteroidal anti-inflammatory drugs; NSAIDs), leading to hyperkalemia and metabolic hyperchloremic acidosis $[73,74]$. Heparin impairs aldosterone synthesis as a result of direct toxicity to the zona glomerulosa, with inhibition of aldosterone synthase (adrenal 18-hydroxylase). Additionally, heparin can decrease the number and affinity of angiotensin II receptors in the adrenal zona glomerulosa $[75,76]$. There is also an effect of lowmolecular-weight heparin on $\mathrm{K}^{+}$levels $[77,78]$. ACE inhibitors and AT2RA can cause hyperkalemia and acidosis, particularly in patients with advanced renal insufficiency [79-81]. The risk of hyperkalemia is increased by simultaneous administration of ACE inhibitors and heparin [82].

Secondary to drugs that interfere with $\mathrm{Na}^{+}$-channel function

$\mathrm{K}^{+}$-sparing diuretics and mineralocorticoid receptor antagonists (e.g., spironolactone, eplerenone, amiloride, triamterene) can lead to moderate hyperchloremic metabolic acidosis. This is the result of inhibition of $\mathrm{Na}^{+}$-reabsorbing $\mathrm{ENaC}$ in the collecting duct, which impairs creation of the lumennegative voltage gradient and inhibits renal electrogenic distal $\mathrm{H}^{+}$secretion into the tubular lumen . In addition, the impaired $\mathrm{K}^{+}$secretion by principal cells results in an increase in serum $\mathrm{K}^{+}$levels [83-85]. Coexisting hyperkalemia impairs renal ammoniagenesis [86], tand These two effects reduce distal $\mathrm{H}^{+}$secretion.

Figure 2 demonstrates how drug interplay affects proximal tubule cells and the thick ascending limb of the loop of Henle. In this depiction, gentamicin enters the proximal tubule cell via the megalin-cubilin system. In the thick ascending, limb aminoglycosides can stimulate the calcium-sensing receptor (CaSR). As a consequence, the function of mitochondrial ribosomes and conversion of ADP to ATP can be disturbed and the $\mathrm{Na}^{+} / \mathrm{K}^{+}$-ATPase pump is inhibited. CaSR activation in the thick ascending limb cell could impair electrolyte transport via inhibition of four different pathways: the kidney-specific $\mathrm{Na}^{+} / \mathrm{K}^{+} / \mathrm{Cl}^{-}$symporter (NKCC2), renal outer medullary potassium channel (ROMK), and $\mathrm{Na}^{+} / \mathrm{K}^{+}$-ATPase and/or paracellular diffusion. This results in increased urinary excretion of $\mathrm{Na}^{+}, \mathrm{K}^{+}$, magnesium $\left(\mathrm{Mg}^{2+}\right)$ and $\mathrm{Ca}^{2+}$. Tetracyclines could enter the proximal tubule cell through apical or basolateral organic anion transporters (OATs) and inhibit the $\mathrm{Na}^{+} / \mathrm{K}^{+}$-ATPase pump.

Figure 3 demonstrateshow drugs that interfere with collecting-duct principal and intercalated cells. Trimethoprim and amiloride inhibit ENaC, causing $\mathrm{Na}^{+}$wasting, reducing kaliuresis, and causing distal RTA via a decrease in $\mathrm{H}^{+}$excretion. Penicillin acts as a nonresorbable anion, leading to a luminal negative charge if aldosterone-driven $\mathrm{Na}^{+}$reabsorption is increased. The consequences are $\mathrm{K}^{+}$secretion with hypokalemia. Demeclocycline (a tetracycline) and amphotericin B could cause nephrogenic diabetes insipidus by inhibiting vasopressin-stimulated vasopressin-2-aquaporin-2 (V2-AQP2) signaling. Demeclocycline enters the cell via hOAT1 or 3. The mechanism of V2-AQP2 signaling interruption is still unknown. Amphotericin B might lead to pores in collecting duct cell membranes. This results in $\mathrm{K}^{+}$ waste via inhibition of adenylate cyclase and a back-flux of $\mathrm{H}^{+}$ into the cells, which inhibits urinary $\mathrm{H}^{+}$excretion, resulting in distal RTA.

\section{Trimethoprim}

Similarly, trimethoprim, commonly administered in combination with sulfamethoxazole as cotrimoxazole, can interfere with the $\mathrm{ENaC}$ (Fig. 3) [87].

\section{Pentamidine}

Luminal pentamidine directly and reversibly blocks apical $\mathrm{Na}^{+}$channels in the same way as $\mathrm{K}^{+}$-sparing diuretics, causing a decrease in the electrochemical gradient for both $\mathrm{K}^{+}$and $\mathrm{H}^{+}$secretion in the cortical collecting tubule. This leads to hyperchloremic metabolic acidosis with hyperkalemia [88].

\section{Distal (type 1) renal tubular acidosis with hypokalemia}

Pathophysiology

Distal RTA is characterized by impairment of $\mathrm{H}^{+}$secretion by the distal nephron, which results in reduced $\mathrm{NH}_{4}{ }^{+}$excretion. Primary distal RTA occurs in children, and clinical features 
Fig. 2 Interplay of drugs that affect proximal tubule cells and thick ascending limb of the loop of Henle. $\mathrm{Ca}^{2+}$ calcium ions, CaSR calcium-sensing receptor, $C l$ chloride ions, $K^{+}$potassium ions, $\mathrm{Mg}^{2+}$ magnesium ions, $\mathrm{Na}^{+}$ sodium ions, $N K C C 2$ kidneyspecific $\mathrm{Na}^{+} / / \mathrm{K}^{+} / \mathrm{Cl}$ symporter, $R O M K$ renal outer medullary potassium channel, $H^{+}$hydrogen ions, $h O A T$ organic anion transporter, collecting-duct principal and intercalated cells. $A C$ adenylate cyclase, $A Q P 2$ aquaporin 2, cAMP cyclic adenosine monophosphate (AMP), ENaC epithelial sodium channel, $h O A T$ organic anion transporter, $K^{+}$potassium ions, $\mathrm{Na}^{+}$sodium ions, $V 2$ vasopressin 2 receptor. $H^{+}$hydrogen ions. Adapted from [185], with permission
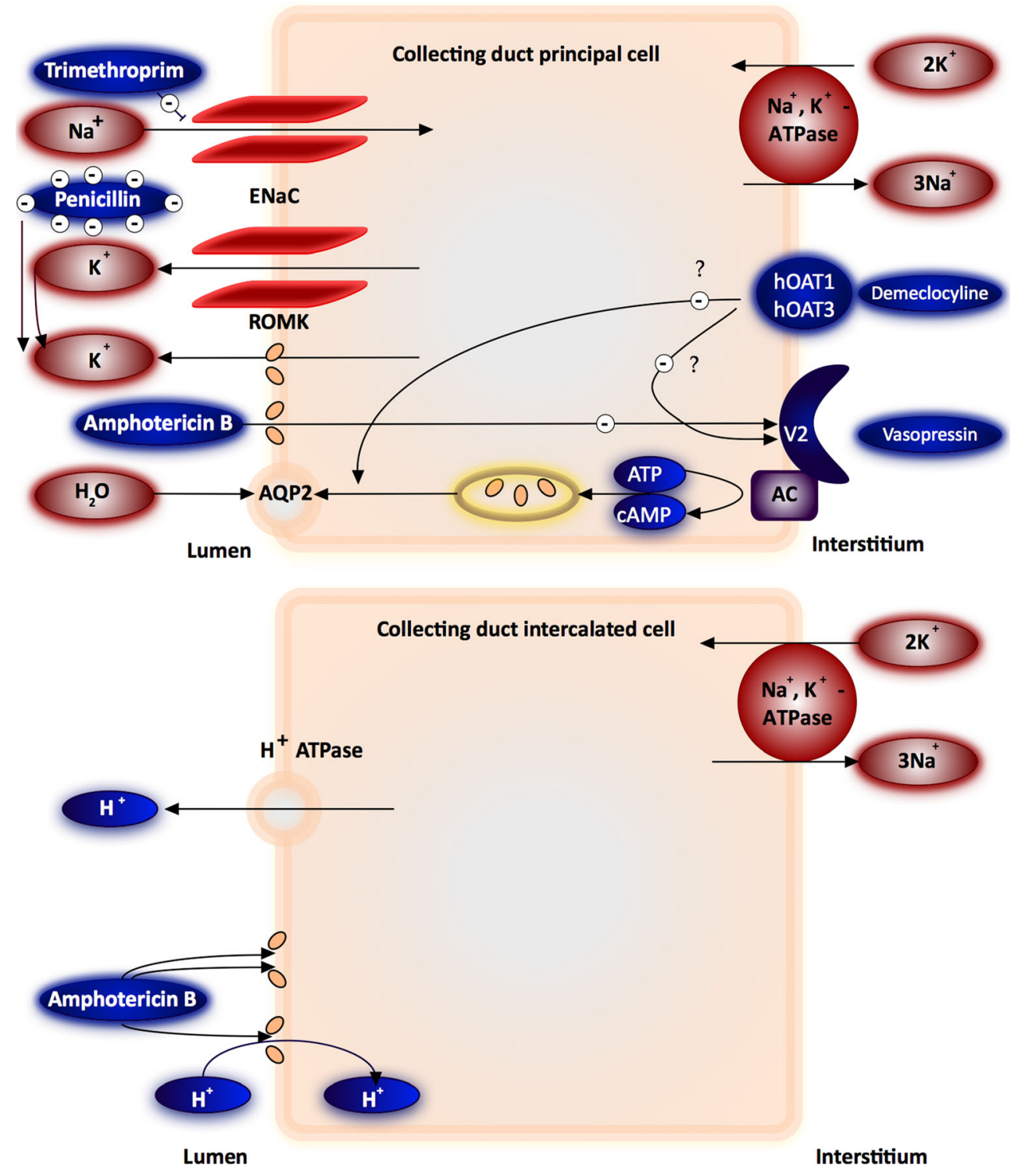

include growth impairment, polyuria, hypercalciuria, nephrocalcinosis, nephrolithiasis, and $\mathrm{K}^{+}$depletion [89]. Furthermore, distal RTA is associated with a variety of genetic diseases in childhood. In adults, autoimmune and renal diseases play an important role in secondary distal RTA [90]. Additionally, distal RTA presents as normochloremic metabolic acidosis with elevated AG. Urinary findings are at first glance similar to hyperkalemic RTA (type 4), but serum $\mathrm{K}^{+}$levels and fractional urinary $\mathrm{K}^{+}$excretion $\left(\mathrm{fK}^{+} \mathrm{e}\right)$ are different (Fig. 1). Distal RTA is accompanied by normal or decreased serum $\mathrm{K}^{+}$levels and increased $\mathrm{fK}^{+} \mathrm{e}$ in the urine (rarely, a small proportion of patients with hyperkalemic distal RTA present with decreased $\mathrm{fK}^{+} \mathrm{e}$ ). Remarkably, drugs might cause distal RTA in a proportion of patients.

\section{Amphotericin B}

Amphotericin B can bind to cholesterol in mammalian cell membranes and modify their ion permeability. This results in a broad spectrum of renal toxic effects [91]. In addition to the effects of amphotericin B on membrane permeability to monovalent cations, there is a direct effect on tubular function. Amphotericin B induces RTA type 1 by increasing membrane permeability in the collecting duct. This results in backdiffusion of secreted $\mathrm{H}^{+}$ions and $\mathrm{K}^{+}$wasting, which leads to hypokalemia [92, 93]. Patients with significant proteinuria ( $>3 \mathrm{~g} / \mathrm{l})$ seem to have a reduced risk of renal tubular toxic effects caused by amphotericin B [94], which might be related to a reduced concentration of free amphotericin B in tubular fluid. 
Fig. 3 Drugs that interfere with frameworks of collecting-duct principal and intercalated cells. $A C$ adenylate cyclase, $A Q P 2$ aquaporin $2, c A M P$ cyclic adenosine monophosphate (AMP), $E N a C$ epithelial sodium channel, $h O A T$ organic anion transporter, $K^{+}$potassium ions, $\mathrm{Na}^{+}$sodium ions, $\mathrm{V} 2$ vasopressin 2 receptor. $H^{+}$hydrogen ions. Adapted from [185], with permission
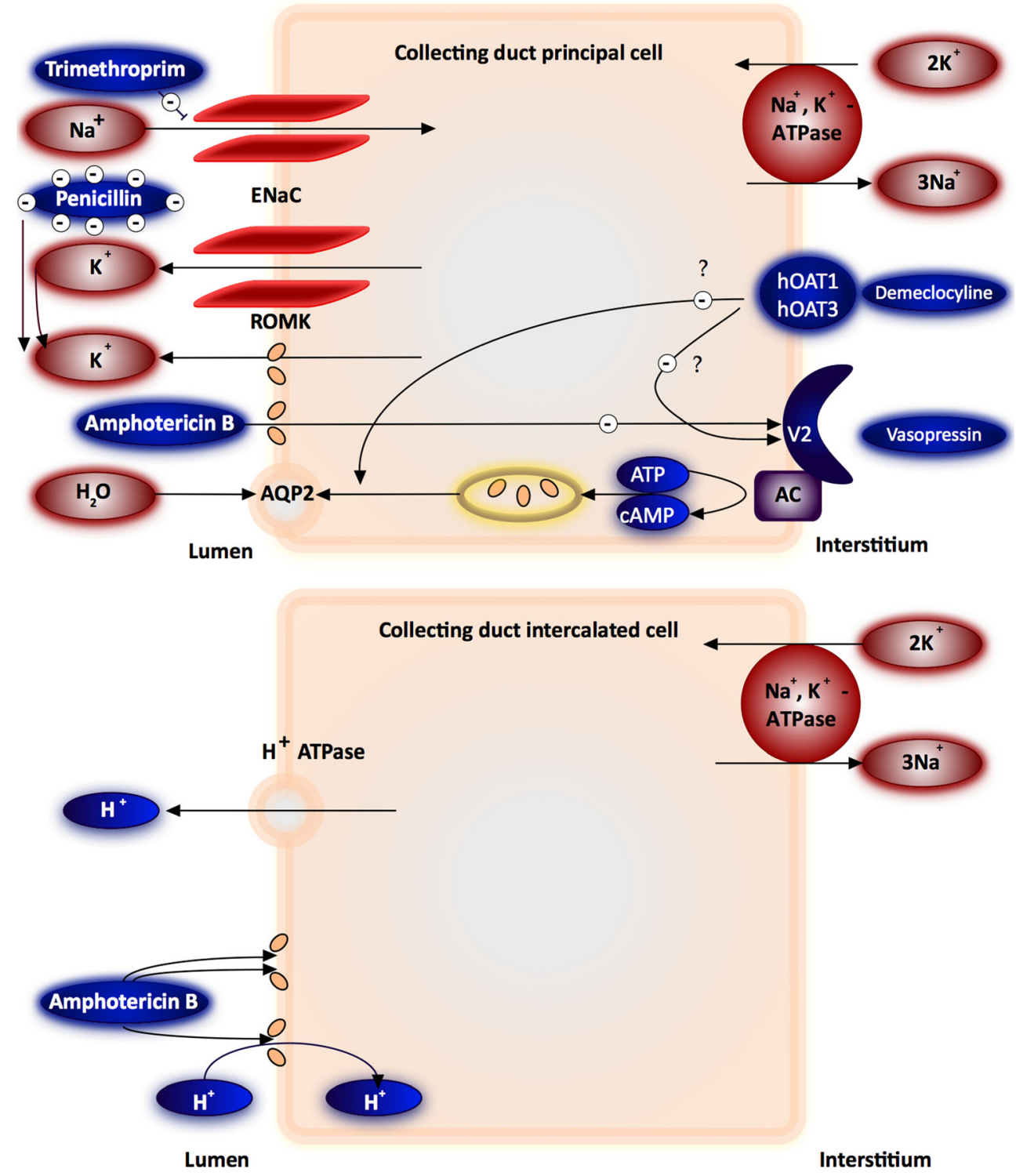

RTA is a rare side effect in amphotericin B therapy [95]. Polyuria and nephrogenic diabetes insipidus are more frequent findings in patients during amphotericin B therapy [96]. Often, there is a combination of RTA and nephrogenic diabetes insipidus (Fig. 3) [97].

\section{Foscarnet}

Foscarnet is a structural mimic of the anion pyrophosphate, which selectively inhibits pyrophosphate-binding sites of various viral DNA sequences and inhibits viral nucleic acid synthesis. The drug needs no prior metabolic activation by viral or cellular enzymes. It is used in immune-compromised patients with life-threatening herpes simplex or cytomegalovirus infections [98, 99]. Intensive IV hydration dramatically reduces the incidence of foscarnet-induced acute kidney injury [100]. Foscarnet can lead to acute tubular toxicity; rarely, a direct effect on tubular function can be detected, which may lead to mitochondrial dysfunction, inducing mitochondrial DNA (mtDNA) in renal tubule cells [101]. This can result in distal RTA [102].

\section{Renal loss of bicarbonate (hyperchloremic metabolic acidosis with normal anion gap)}

Proximal renal tubular acidosis in the context of drug-induced renal Fanconi syndrome

\section{Pathophysiology}

Proximal RTA (type 2) is caused by impairment of $\mathrm{HCO}_{3}{ }^{-}$ reabsorption in the proximal tubule, leading to $\mathrm{HCO}_{3}{ }^{-}$ 
wasting. Patients present with hyperchloremic metabolic acidosis with normal serum AG. However, distal $\mathrm{H}^{+}$secretion is still intact, which leads to urine $\mathrm{pH}<5.5$. If plasma $\mathrm{HCO}_{3}{ }^{-}$ concentration is normalized by administration of alkali, urine $\mathrm{pH}$ is increased. Furthermore, there is a negative urine AG ( $\geq 15 \mathrm{mmol} / \mathrm{l}$ ) in proximal RTA. Diagnosis of proximal RTA is confirmed after exclusion of $\mathrm{GI} \mathrm{HCO}_{3}{ }^{-}$loss or excessive use of laxatives (Fig. 1). Proximal RTA may be primary [103, 104] or accompanied by other proximal tubular defects in the context of Fanconi syndrome. Drug therapy often causes secondary proximal RTA and is often associated with druginduced renal Fanconi syndrome (RFS), with generalized dysfunction of the proximal tubule system and $\mathrm{HCO}_{3}{ }^{-}$loss. Furthermore, a variety of clinical entities (e.g., vitamin D deficiency, hyperparathyroidism, congenital heart disease, Alport syndrome, corticoresistant nephrotic syndrome, renal transplantation, amyloidosis, and recurrent nephrolithiasis) could cause proximal RTA. In children with metabolic acidosis and growth impairment, it is mandatory to differentiate between proximal RTA and RFS, because correction of metabolic acidosis can improve growth in proximal RTA but not in RFS [105].

\section{Ifosfamide}

Ifosfamide, a structural analog of the oxazaphosphorine cyclophosphamide, is an alkylating agent. Since the 1980s, ifosfamide has been the standard therapy for childhood softtissue and bone sarcomas and is also used to treat germinal tumors. There are various renal side effects associated with ifosfamide. Toxicity involves mainly the proximal-and in rare cases, the distal-renal tubules [106]. It leads to ifosfamide-induced proximal tubulopathy, which results in a loss of phosphate and $\mathrm{HCO}_{3}{ }^{-}$(proximal RTA) [107]. In a study of 75 patients, the incidence of acidosis was $7 \%$ [108]. In another study of 22 children, proximal tubular, glomerular, and distal tubular impairment (in descending order of frequency) was identified [109].

Proximal RTA as an isolated defect in $\mathrm{HCO}_{3}{ }^{-}$reabsorption is rarely observed. It is characterized by a decrease in $\mathrm{HCO}_{3}{ }^{-}$ reabsorption in the proximal tubule, without any modification in the transport of other solutes. This disturbance is characterized by a decrease in the threshold value for $\mathrm{HCO}_{3}{ }^{-}$reabsorption [90, 110]. A more frequent $\mathrm{ABD}$ in patients receiving ifosfamide is RFS [111, 112], a disorder of the proximal tubule cell associated with RTA in combination with glycosuria, aminoaciduria, phosphaturia, and normal AG [113]. Proximal RTA in the context of RFS is not rare in patients treated with ifosfamide (4.6\% of patients). Risk factors include cumulative dose of ifosfamide and younger age [106]. The frequency of subclinical tubular dysfunction is up to $90 \%[114,115]$. However, there is also a report of complete recovery after severe RFS [116].
There are reports that one metabolite of ifosfamide, chloroacetaldehyde (CAA), can cause renal injury by inhibiting nicotinamide adenine dinucleotide (NADH), resulting in inhibition of ubiquinone oxidoreductase, an important enzyme in the oxidative phosphorylation pathway of the cell. Another suspected pathway in rat proximal tubules is endocytosis inhibition resulting from CAA-induced decrease in ATP levels [117].

\section{Oxaplatin and cisplatin}

Platin-induced proximal RTA has been described as both isolated proximal RTA and as part of RFS [118-120]. Cisplatin-induced RFS is caused by a direct toxic effect on the amino acid transporter in the proximal convoluted tubule. This can be caused by an effect similar to that of aminoglycoside toxicity. Aminoglycosides reduce glucose reabsorption in kidney tissue by reducing mRNA and protein expression and by disrupting the sodium-dependent glucose transporter (SGLT1) function, which is located in the apical membrane of the proximal tubule [121]. This causes a reduction in glucose reabsorption in the kidney [122]. It has been suggested that one possible mechanism of cisplatin-induced proximal tubule toxicity is reduced expression of SGLTs [121, 123]. However, in patients with familial renal glucosuria (mutations in SGLT1/SGLT2 coding gene, SLC5A2), no acid-base homeostasis disturbances have been reported [124, 125].

\section{Acetazolamide (carbonic anhydrase inhibitors)}

Acetazolamide is used to treat idiopathic intracranial hypertension (pseudotumor cerebri) in children and particularly in obese women of childbearing age but also adult patients with glaucoma. It is well known that carbonic anhydrase (CA) inhibitors cause isolated proximal RTA [111]. There are two main isoforms of CA in the kidneys: membrane-bound and cytoplasmic: CA IV and CA II, respectively [126, 127]. Both isoforms play an important role. CA II is widely distributed in the various compartments of the kidney and is present in almost all cell types. The membrane-bound CA IV is mainly located in the proximal tubule and is absent from or poorly expressed in the collecting duct and the proximal tubule [127]. Defects in $\mathrm{HCO}_{3}{ }^{-}$reabsorption cause inhibition of CA IV in the apical membrane of the proximal tubule cell. The inhibition of CA IV leads to an isolated blocking of the membranebound CA IV isoform, which causes an isolated inhibition of $\mathrm{HCO}_{3}{ }^{-}$reabsorption without signs of RFS [128, 129].

\section{Antiretrovirals}

Human immune deficiency (HIV) infection represents one of the most serious pediatric diseases worldwide, with an estimated 3.3 million children younger than 15 years being 
infected [130]. Currently available antiretroviral therapy (ART) utilizes five major classes of antiretroviral (ARV) drugs: nucleoside/nucleotide analog reverse transcriptase inhibitors (NRTIs/NtRTIs), nonnucleoside RTIs (NNRTIs), protease inhibitors (PIs), entry and fusion inhibitors, and integrase inhibitors. Combination ART, also defined as highly active ART (HAART), is composed of three ARV drugs from at least two major classes in order to achieve maximal suppression of HIV replication and preserve immune function disrupted by HIV.

Tenofovir disoproxil fumarate (TDF) is an NtRTI that has been licensed by the FDA for use in children $>2$ years of age [131]; TDF can cause FS [132]. Several mechanisms of TDF nephrotoxicity have been investigated: It enters proximal tubule cells through basolateral OATs and exits by using an apical transporter, the multidrug-resistance-associated protein 4 (MRP 4) $[133,134]$. TDF toxicity in the proximal tubule cell can lead to damaged and dysmorphic mitochondria, with loss of matrix cristae; in some cases, it can result in giant mitochondria. Phosphate is reabsorbed from the glomerular filtrate across the apical proximal tubule membrane by the $\mathrm{Na}^{+}$-phosphate cotransporter subtype 2a (NaPi-IIa). Mitochondrial failure leads to energy failure and impaired phosphate transport, leading to urinary phosphate wasting.

There are various treatments for TDF toxicity. Probenecid is increases uric acid excretion and is primarily used to treat gout and hyperuricemia. Probenecid inhibits TDF uptake into proximal tubule cells by OATs. Rosiglitazone binds to peroxisome-proliferator-activated receptor- $\gamma$ (PPAR- $\gamma)$ and causes an increase in $\mathrm{NaPi}$ expression. Treatment with rosiglitazone increases expression levels of $\mathrm{NaPi}$-IIa and sodium-hydrogen exchanger 3 (NHE3), acting against electrolyte and acid-base disturbances caused by TDF $[135,136]$.

\section{Valproic acid}

In rare cases, long-term treatment with valproic acid can also cause FS. There are some case reports of FS developing in patients on long-term valproic acid therapy [137-140]. The mechanism of valproic acid toxicity is not clear. A direct toxic effect on mitochondria of the proximal tubules has been suggested [141, 142].

Aminoglycosides and tetracyclines

Aminoglycosides and tetracyclines can affect proximal tubular function and cause fluid and electrolyte disorders. Gentamicin can interfere with specific transport mechanisms in the primal tubular system or can induce RFS. Usually, aminoglycoside-induced RFS is seen in patients with impaired renal function, but some reports of patients with normal kidney function exist [143]. Gentamicin enters the cell through the megalin-cubulin system [41]. Intracellular gentamicin can decrease the function of mitochondrial ribosomes [144] and interfere with the conversion of ADP to ATP [145]. Consequently, gentamycin inhibits the $\mathrm{Na}^{+} / \mathrm{K}^{+}$-ATPase pump, which is dependent upon ATP, and inhibits NHE-3 and other $\mathrm{Na}^{+}$-dependent solute transporters, including transporters for amino acids, uric acid, and glucose (Fig. 2) [146].

The second group of antibiotics that causes RFS are the tetracyclines, which can cause proximal tubular damage within 1 week after start of therapy [147]. Tetracyclines enter the proximal tubule cell via apical or basolateral OATs. Basolateral transport of tetracyclines into the tubule cell is mediated by OATs 1,2 , and 3 , and reabsorption from the luminal side of the tubule cell is mediated by OAT 4 [148]. Similar to the toxic mechanism of aminoglycosides, tetracyclines can impair the function of mitochondrial ribosomes (Fig. 2) [149, 150].

\section{Metabolic alkalosis}

Pathophysiology

Metabolic alkalosis is a common but often underdiagnosed ABD in hospitalized patients [90]. However, metabolic alkalosis may contribute to increased mortality in hospitalized and critically ill patients [151-153]. Increased blood $\mathrm{pH}$ may disturb the respiratory center and lead to respiratory depression $[154,155]$. Furthermore, metabolic alkalosis leads to a shift in the oxygen dissociation curve of hemoglobin, which could cause hypoxemia [156]. Additionally, alkalosis leads to vasoconstriction, and the subsequent decreased blood flow could compound hypoxemia of peripheral tissue. Appropriately, it has been demonstrated in humans that alkalosis might cause coronary vasoconstriction and angina [156, 157]. In patients with metabolic alkalosis, it is mandatory to distinguish between a disturbed $\mathrm{HCO}_{3}{ }^{-}$clearance caused by renal failure and metabolic alkalosis, which is maintained by a decreased effective arterial blood volume (EABV) or in which alkalosis is maintained by the combination of high aldosterone and high distal $\mathrm{Na}^{+}$delivery. The first step in analyzing metabolic alkalosis is determining EABV. The next step involves analyses of urinary electrolytes (Fig. 1). In patients with decreased EABV and decreased urine $\mathrm{Cl}^{-}$, urine $\mathrm{Na}^{+}$ should be measured to distinguish between the two most common reasons for metabolic alkalosis [chloride-depletion alkalosis (CDA) under remote use of diuretics, and loss of $\mathrm{Na}^{+}$ and $\mathrm{Cl}^{-}$via the gastrointestinal tract]. Furthermore, acid loss with $\mathrm{Cl}^{-}$depletion without loss of $\mathrm{Na}^{+}$occurs in active vomiting and nasogastric suction. In patients with decreased EABV and increased urine $\mathrm{Cl}^{-}$, diuretic use with increased 
natriuresis or Bartter syndrome should be considered. In patients with hypercalcemia, metabolic alkalosis with or without renal failure calcium-alkali syndrome must be taken into consideration.

\section{Renal acid and/or chloride and potassium loss (CDA)}

Loop and thiazide diuretics

High doses of loop and thiazide diuretics can lead to metabolic alkalosis, which can result in diuretic resistance [158]. Severe metabolic alkalosis is rare but is usually associated with high dosages of loop diuretics [159]. Three phases have been distinguished: (1) generation, (2) maintenance, and (3) recovery. In 1965, Cannon et al. [160] established the concept of "contraction alkalosis" in the context of loop diuretics. They suggested that distal $\mathrm{H}^{+}$excretion with renal acid loss and rapid contraction of the extracellular fluid (ECF) volume at constant extracellular $\mathrm{HCO}_{3}{ }^{-}$leads to metabolic alkalosis. It was observed that $\mathrm{Cl}^{-}$loss influences $\mathrm{HCO}_{3}{ }^{-}$ reabsorption [161]. The concept of contraction alkalosis is still widely used, but the preferred term is now chloride-depletion alkalosis (CDA). Recently, Luke et al. showed that CDA can be corrected by selective $\mathrm{Cl}^{-}$administration despite continued or increased negative $\mathrm{Na}^{+}$or $\mathrm{K}^{+}$balance, continuing $\mathrm{HCO}_{3}{ }^{-}$loading, and continuing high levels of angiotensin II or aldosterone. CDA is not corrected by $\mathrm{Na}^{+}$or $\mathrm{K}^{+}$administration without $\mathrm{Cl}^{-}$repletion $[162,163]$. CDA persisted in rats infused with albumin that increased ECF by $15 \%$ [163]. CDA was corrected by $\mathrm{Cl}^{-}$infusion and persistent volume depletion and decreased GFR [164]. In summary, $\mathrm{Cl}^{-}$administration without volume expansion is necessary and sufficient to correct CDA, and the term chloride depletion alkalosis should be used instead of contraction alkalosis. In the maintenance phase of CDA, pendrin activity is increased but $\mathrm{HCO}_{3}{ }^{-}$secretion is inhibited due to the reduced $\mathrm{Cl}^{-}$delivery for anion exchange with $\mathrm{HCO}_{3}{ }^{-}$. From a therapeutic point of view, at this step, substitution of $\mathrm{Cl}^{-}$is mandatory. After $\mathrm{Cl}^{-}$substitution, $\mathrm{HCO}_{3}{ }^{-}$secretion increases and medullary $\mathrm{HCO}_{3}{ }^{-}$reabsorption decreases [186]. This leads to bicarbonaturia, with adjustment of hypochloremic alkalosis (Fig. 4).

\section{Penicillins}

Penicillins are frequently used worldwide and have a large therapeutic window. Hypokalemia has been reported in patients receiving penicillin derivatives [165]. It has been suspected that penicillins act as nonreabsorbable anions, which maintain a transmembrane potential gradient that is negative on the lumen side in the cortical collecting duct, while the delivery of $\mathrm{Cl}^{-}$ions in the distal collecting duct is reduced (Fig. 3) [166]. This effect is enhanced by volume depletion, which leads to increased aldosterone synthesis and $\mathrm{K}^{+}$secretion. Laboratory findings in patients with hypokalemia are a low urinary $\mathrm{Cl}^{-}$concentration and decreased $\mathrm{K}^{+}$ levels in urine, in combination with a metabolic alkalosis. Additionally, severe hypokalemia has been reported in patients treated with flucloxacillin: $\mathrm{Cl}^{-}$level in urine was increased, suggesting that an additional direct penicillin-induced tubule toxicity occurs [167].

\section{Aminoglycosides}

Aminoglycosides affect the tubular system in the thick ascending limb of the loop of Henle. It has been hypothesized that gentamicin activates the CaSR in this area and in the distal convoluted tubule [168-170]. Under physiological conditions, the increased serum $\mathrm{Ca}^{2+}$ levels stimulate this receptor and decrease the active reabsorption of $\mathrm{Na}^{+}$. This reduces the luminal positive driving force and results in increased urinary $\mathrm{Ca}$ excretion [171]. Activation of the CaSR can disrupt electrolyte transport via inhibition of four different pathways: (1) renal channel proteins, such as the $\mathrm{Na}-\mathrm{K}-2 \mathrm{Cl}$ cotransporter (NKCC2), (2) ROMK, (3) $\mathrm{Na}^{+} / \mathrm{K}^{+}$-ATPase, and (4) paracellular diffusion [146]. Inhibition of these transport mechanisms leads to increased urinary excretion of $\mathrm{Na}^{+}, \mathrm{K}^{+}$, $\mathrm{Mg}^{2+}$, and $\mathrm{Ca}^{2+}$ (Fig. 2). This results in hypokalemic metabolic alkalosis with hypermagnesuria and hypercalciuria and a normal serum creatinine (Bartter-like syndrome) [172, 173]. Furthermore, gentamicin might cause $\mathrm{Mg}^{2+}$ wasting; animal experiments have shown a causal relationship between gentamicin administration and $\mathrm{Mg}^{2+}$ wasting [174]. In healthy people, gentamicin causes immediate and transient renal calcium $\left(\mathrm{Ca}^{2+}\right)$ and $\mathrm{Mg}^{2+}$ wasting (Fig. 2) [175].

\section{Extrarenal acid and/or chloride loss (chloride-depletion metabolic alkalosis)}

Laxative abuse in adults (e.g., bisacodyl, sodium picosulfate, saline laxatives, lactulose, and cisapride) results in electrolyte disturbances (mainly hypokalemia), metabolic alkalosis, and renal tubular dysfunction [176]. Laxative abuse occurs in children with, for example, Munchausen's syndrome, by proxy and in adolescents with eating disorders [177]. Therefore, this should be especially considered in patients with unexplainable chloride-depletion metabolic alkalosis (CDA). 
Fig. 4 Different phases of chloride-depletion alkalosis (CDA). $\mathrm{K}^{+}$, potassium ions; $\mathrm{Na}^{+}$, sodium ions; $\mathrm{Cl}$, chloride ions; $\mathrm{H}^{+}$, hydrogen ions; $\mathrm{HCO}_{3}^{-}$, bicarbonate; $E N a C$, epithelial sodium channel; $P n$, pendrin (sodium-independent chloride/ iodide transporter); $A E I$, anion exchanger isoform 1. Adapted from [186], with permission

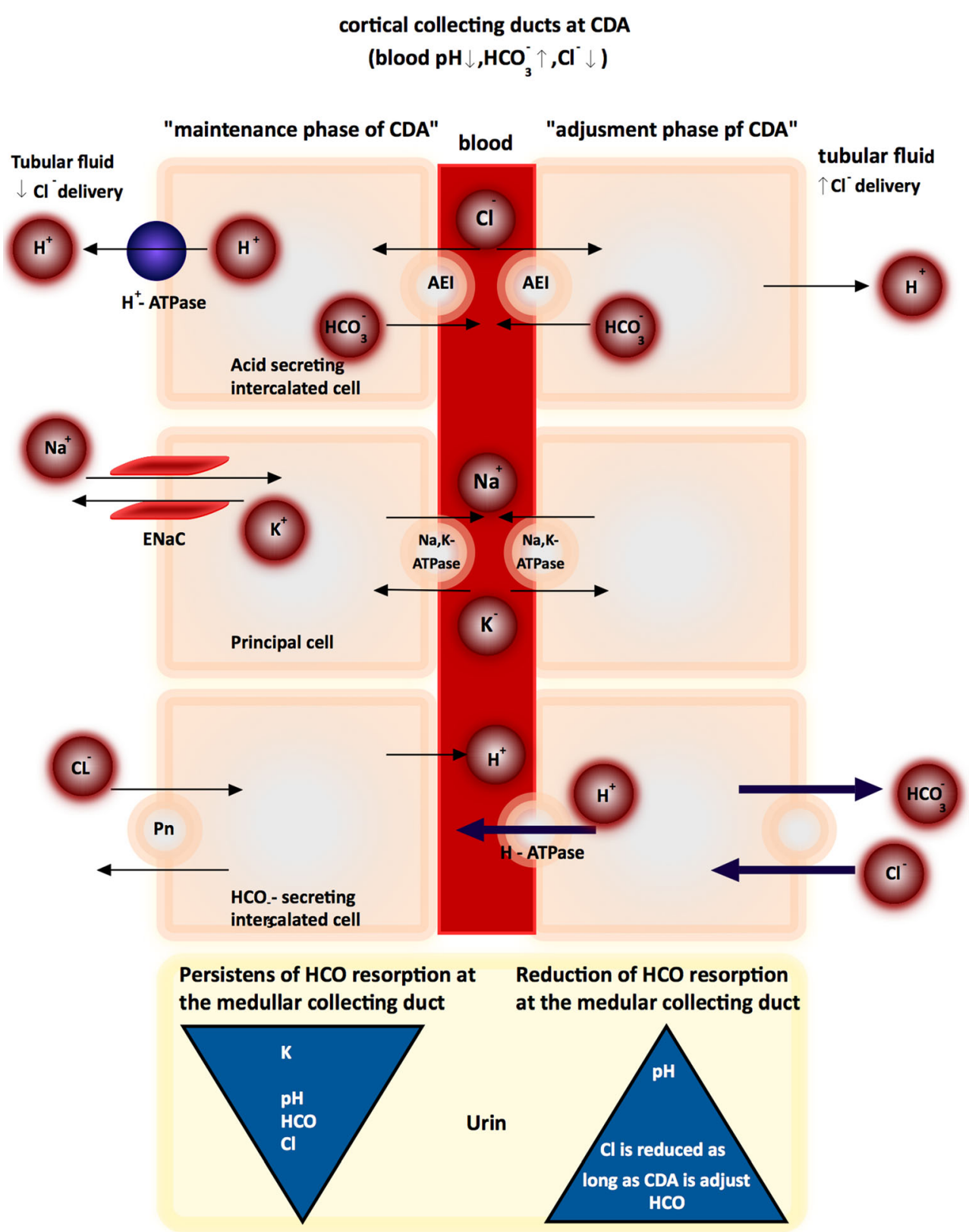

\section{Alkali administration (non-chloride-depletion metabolic alkalosis)}

Milk-alkali or calcium-alkali syndrome

Milk-alkali syndrome was a very common cause of hypercalcemia, metabolic alkalosis, and renal failure at the beginning of the last century. The syndrome was associated with the ingestion of large quantities of milk and absorbable alkali to treat peptic ulcer disease [178]. Nowadays, this syndrome is called calcium-alkali syndrome (CAS) [179]. The incidence of CAS in children is not clear. Vitamin D supplementation to prevent vitamin-D-deficient rickets in children is generally recommended [180], but there are some reports of children with hypercalcemia after treatment with vitamin D [181]. The classic symptoms consist of hypercalcemia, various degrees of renal failure, and metabolic alkalosis [182]. There are several risk factors for development of CAS: The use of thiazide diuretics predisposes to CAS by increasing $\mathrm{Ca}^{2+}$ reabsorption in combination with volume depletion and metabolic alkalosis. ACE inhibitors and NSAIDs increase the risk of CAS by reducing GFR, leading to decreased $\mathrm{Ca}^{2+}$ excretion [183]. The increased serum $\mathrm{Ca}^{2+}$ levels (via increased intestinal supply or elevated vitamin D levels) lead to activation of the CaSR in the thick ascending limb of Henle and the medullary collecting duct and to parathyroid hormone suppression. Concomitant metabolic alkalosis also increases tubular reabsorption of $\mathrm{Ca}^{2+}$. 


\section{Key summary points}

- Drug- nduced ABDs are frequently present in hospitalized patients.

- Analysis of ABDs should be performed systematically in a standardized manner.

- Drug-induced ABDs can be classified into five different categories in terms of pathophysiology:

- (1) Metabolic acidosis caused by acid overload

- (2) Base loss

- (3) Alkalosis resulting from acid loss

- (4) Exogenous $\mathrm{HCO}_{3}{ }^{-}$loads

- (5) Respiratory acidosis or alkalosis resulting from druginduced depression of the respiratory center or neuromuscular impairment

- Chloride administration without volume expansion is necessary and sufficient to correct CDA, and the term chloride-depletion alkalosis should be used instead of contraction alkalosis.

\section{Multiple-choice questions (answers are provided} following the reference list)

Q1: A newborn developed diarrhea at day 10 after birth, and on the subsequent day, lethargy and refusal to eat. Rapidly, he developed diffuse cyanosis, hypotonia, and areflexia. After symptom onset, he was immediately transferred to the intensive care unit. First blood gas analyses showed: $\mathrm{pH}$ 6.9, $\mathrm{pCO}_{2} 29.8 \mathrm{mmHg}, \mathrm{pO}_{2} 90.1 \mathrm{mmHg}$ (under oxygen therapy), $\mathrm{HCO}_{3}{ }^{-} 3 \mathrm{mEq} / \mathrm{l}$, base excess 22, lactic acid $17 \mathrm{mmol} / \mathrm{l}$ (nor$\mathrm{mal}<2 \mathrm{mmol} / \mathrm{l})$. What kind of disturbance is present?
(a) Metabolic acidosis
(b) Respiratory alkalosis
(c) Metabolic alkalosis
(d) Respiratory acidosis

Q2: A 14-year-old boy receives chronic furosemide treatment. The dose of furosemide was accidentally increased for 10 days. His medical history was notable for the diagnosis of severe heart failure due to myocarditis at the age of 12 years. What acid-base disorder would you expect?

(a) Hyperchloremic metabolic acidosis

(b) Hypochloremic metabolic alkalosis

(c) Normochloremic respiratory alkalosis

(d) Hypochloremic metabolic acidosis

Q3: How would you calculate the AG, and in which cases would you expect to have an increased AG?

(a) $\left(\left[\mathrm{Na}^{+}\right]+\left[\mathrm{K}^{+}\right]\right)+\left(\left[\mathrm{Cl}^{-}\right]+\left[\mathrm{HCO}_{3}{ }^{-}\right]\right)$: diabetic ketoacidosis

(b) $\left(\left[\mathrm{Na}^{+}\right]+\left[\mathrm{K}^{+}\right]\right)-\left(\left[\mathrm{Cl}^{-}\right]-\left[\mathrm{HCO}_{3}{ }^{-}\right]\right)$: uremia (c) $\left(\left[\mathrm{Na}^{+}\right]+\left[\mathrm{K}^{+}\right]\right)-\left(\left[\mathrm{Cl}^{-}\right]+\left[\mathrm{HCO}_{3}{ }^{-}\right]\right)$: diabetic ketoacidosis

(d) $\left(\left[\mathrm{Na}^{+}\right]+\left[\mathrm{K}^{+}\right]\right)+\left(\left[\mathrm{Cl}^{-}\right]+\left[\mathrm{HCO}_{3}^{-}\right]\right)$: uremia

Q4: What acid-base disorder would you expected in patients with propofol infusion syndrome?

(a) Metabolic alkalosis with normal lactate levels

(b) Metabolic acidosis with elevated lactate levels

(c) Respiratory acidosis with normal lactate levels

(d) Respiratory alkalosis with normal lactate levels

Q5: Aminoglycosides might cause which of the following?

(a) Hyperkalemic metabolic acidosis

(b) Hypokalemic respiratory alkalosis

(c) Hyperkalemic metabolic alkalosis

(d) Hypokalemic metabolic alkalosis

Acknowledgments MS was supported by the Robert-Bosch Foundation, Stuttgart, Germany

\section{References}

1. Kraut JA, Madias NE (2007) Serum anion gap: its uses and limitations in clinical medicine. Clin J Am Soc Nephrol 2:162-174

2. Palmer BF, Alpern RJ (1997) Metabolic alkalosis. J Am Soc Nephrol 8:1462-1469

3. Ishihara K, Szerlip HM (1998) Anion gap acidosis. Semin Nephrol 18:83-97

4. Gluck SL (1998) Acid-base. Lancet 352:474-479

5. Adrogue HJ (2006) Metabolic acidosis: pathophysiology, diagnosis and management. J Nephrol Nurs 19(Suppl 9):S62-S69

6. Lorenz JM, Kleinman LI, Markarian K, Oliver M, Fernandez J (1999) Serum anion gap in the differential diagnosis of metabolic acidosis in critically ill newborns. J Pediatr 135:751-755

7. Winter SD, Pearson JR, Gabow PA, Schultz AL, Lepoff RB (1990) The fall of the serum anion gap. Arch Intern Med 150:311-313

8. Singh RN, Singh NC, Hutchison J, Moses GC (1994) Lower anion gap increases sensitivity in predicting elevated lactate. Clin Intensive Care 5:221-224

9. Sadjadi SA, Manalo R, Jaipaul N, McMillan J (2013) Ion-selective electrode and anion gap range: what should the anion gap be? Int $\mathrm{J}$ Nephrol Renov Dis 6:101-105

10. Hatherill M, Waggie Z, Purves L, Reynolds L, Argent A (2002) Correction of the anion gap for albumin in order to detect occult tissue anions in shock. Arch Dis Child 87:526-529

11. Feldman M, Soni N, Dickson B (2005) Influence of hypoalbuminemia or hyperalbuminemia on the serum anion gap. J Lab Clin Med 146:317-320

12. Figge J, Jabor A, Kazda A, Fencl V (1998) Anion gap and hypoalbuminemia. Crit Care Med 26:1807-1810

13. Kruse JA, Cadnapaphornchai P (1994) The serum osmole gap. J Crit Care 9:185-197

14. McQuillen KK, Anderson AC (1999) Osmol gaps in the pediatric population. Acad Emerg Med 6:27-30 
15. Wrenn K (1990) The delta (delta) gap: an approach to mixed acidbase disorders. Ann Emerg Med 19:1310-1313

16. Rastegar A (2007) Use of the DeltaAG/DeltaHCO3- ratio in the diagnosis of mixed acid-base disorders. J Am Soc Nephrol 18: 2429-2431

17. Adrogue HJ, Wilson H, Boyd AE 3rd, Suki WN, Eknoyan G (1982) Plasma acid-base patterns in diabetic ketoacidosis. N Engl J Med 307:1603-1610

18. Goldstein MB, Bear R, Richardson RM, Marsden PA, Halperin ML (1986) The urine anion gap: a clinically useful index of ammonium excretion. Am J Med Sci 292:198-202

19. Kirschbaum B, Sica D, Anderson FP (1999) Urine electrolytes and the urine anion and osmolar gaps. J Lab Clin Med 133:597-604

20. Batlle DC, Hizon M, Cohen E, Gutterman C, Gupta R (1988) The use of the urinary anion gap in the diagnosis of hyperchloremic metabolic acidosis. N Engl J Med 318:594-599

21. Gonzalez E, Gutierrez E, Galeano C, Chevia C, de Sequera P, Bernis C, Parra EG, Delgado R, Sanz M, Ortiz M, Goicoechea M, Quereda C, Olea T, Bouarich H, Hernandez Y, Segovia B, Praga M (2008) Early steroid treatment improves the recovery of renal function in patients with drug-induced acute interstitial nephritis. Kidney Int 73: 940-946

22. Rougier F, Claude D, Maurin M, Maire P (2004) Aminoglycoside nephrotoxicity. Curr Drug Targets CNS Neurol Disord 4:153-162

23. Chiappini E, Conti C, Galli L, de Martino M (2010) Clinical efficacy and tolerability of linezolid in pediatric patients: a systematic review. Clin Ther 32:66-88

24. Dotis J, Iosifidis E, Ioannidou M, Roilides E (2010) Use of linezolid in pediatrics: a critical review. Int J Infect Dis 14:e638-e648

25. Garcia-Prats AJ, Rose PC, Hesseling AC, Schaaf HS (2014) Linezolid for the treatment of drug-resistant tuberculosis in children: a review and recommendations. Tuberculosis (Edinb) 94:93104

26. Saiman L, Goldfarb J, Kaplan SA, Wible K, Edge-Padbury B, Naberhuis-Stehouwer S, Bruss JB (2003) Safety and tolerability of linezolid in children. Pediatr Infect Dis J 22:S193-S200

27. Apodaca AA, Rakita RM (2003) Linezolid-induced lactic acidosis. N Engl J Med 348:86-87

28. Su E, Crowley K, Carcillo JA, Michaels MG (2011) Linezolid and lactic acidosis: a role for lactate monitoring with long-term linezolid use in children. Pediatr Infect Dis J 30:804-806

29. Scotton P, Fuser R, Torresan S, Carniato A, Giobbia M, Rossi C, Inojosa WO, Vaglia A (2008) Early linezolid-associated lactic acidosis in a patient treated for tuberculous spondylodiscitis. Infection 36:387-388

30. De Vriese AS, Coster RV, Smet J, Seneca S, Lovering A, Van Haute LL, Vanopdenbosch LJ, Martin JJ, Groote CC, Vandecasteele S, Boelaert JR (2006) Linezolid-induced inhibition of mitochondrial protein synthesis. Clin Infect Dis 42:1111-1117

31. Garrabou G, Soriano A, Lopez S, Guallar JP, Giralt M, Villarroya F, Martinez JA, Casademont J, Cardellach F, Mensa J, Miro O (2007) Reversible inhibition of mitochondrial protein synthesis during linezolid-related hyperlactatemia. Antimicrob Agents Chemother 51:962-967

32. Soriano A, Miro O, Mensa J (2005) Mitochondrial toxicity associated with linezolid. N Engl J Med 353:2305-2306

33. Palenzuela L, Hahn NM, Nelson RP Jr, Arno JN, Schobert C, Bethel R, Ostrowski LA, Sharma MR, Datta PP, Agrawal RK, Schwartz JE, Hirano M (2005) Does linezolid cause lactic acidosis by inhibiting mitochondrial protein synthesis? Clin Infect Dis 40 : e113-e116

34. Carson J, Cerda J, Chae JH, Hirano M, Maggiore P (2007) Severe lactic acidosis associated with linezolid use in a patient with the mitochondrial DNA A2706G polymorphism. Pharmacotherapy 27: $771-774$
35. Boutoille D, Grossi O, Depatureaux A, Tattevin P (2009) Fatal lactic acidosis after prolonged linezolid exposure for treatment of multidrug-resistant tuberculosis. Eur J Int Med 20:e134-e135

36. McKeage K, Perry CM (2003) Propofol: a review of its use in intensive care sedation of adults. CNS Drugs 17:235-272

37. Rigby-Jones AE, Sneyd JR (2011) Propofol and children-what we know and what we do not know. Paediatr Anaesth 21:247-254

38. Diedrich DA, Brown DR (2011) Analytic reviews: propofol infusion syndrome in the ICU. J Intensive Care Med 26:59-72

39. Bonhomme V, Demoitie J, Schaub I, Hans P (2009) Acid-base status and hemodynamic stability during propofol and sevoflurane-based anesthesia in patients undergoing uncomplicated intracranial surgery. J Neurosurg Anesthesiol 21:112-119

40. Roberts RJ, Barletta JF, Fong JJ, Schumaker G, Kuper PJ, Papadopoulos S, Yogaratnam D, Kendall E, Xamplas R, Gerlach AT, Szumita PM, Anger KE, Arpino PA, Voils SA, Grgurich P, Ruthazer R, Devlin JW (2009) Incidence of propofol-related infusion syndrome in critically ill adults: a prospective, multicenter study. Crit Care 13:R169

41. Koriyama H, Duff JP, Guerra GG, Chan AW (2014) Is propofol a friend or a foe of the pediatric intensivist? Description of propofol use in a PICU*. Pediatr Crit Care Med 15:e66-e71

42. Kruessell MA, Udink ten Cate FE, Kraus AJ, Roth B, Trieschmann U (2012) Use of propofol in pediatric intensive care units: a national survey in Germany. Pediatr Crit Care Med 13:e150-e154

43. Hatch DJ (1999) Propofol-infusion syndrome in children. Lancet 353:1117-1118

44. Kam PC, Cardone D (2007) Propofol infusion syndrome. Anaesthesia 62:690-701

45. Koch M, De Backer D, Vincent JL (2004) Lactic acidosis: an early marker of propofol infusion syndrome? Intensive Care Med 30:522

46. Wolf A, Weir P, Segar P, Stone J, Shield J (2001) Impaired fatty acid oxidation in propofol infusion syndrome. Lancet 357:606-607

47. Withington DE, Decell MK, Al Ayed T (2004) A case of propofol toxicity: further evidence for a causal mechanism. Paediatr Anaesth 14:505-508

48. Kraut JA, Kurtz I (2008) Toxic alcohol ingestions: clinical features, diagnosis, and management. Clin J Am Soc Nephrol 3:208-225

49. Zar T, Graeber C, Perazella MA (2007) Recognition, treatment, and prevention of propylene glycol toxicity. Semin Dial 20:217-219

50. Tayar J, Jabbour G, Saggi SJ (2002) Severe hyperosmolar metabolic acidosis due to a large dose of intravenous lorazepam. N Engl J Med 346:1253-1254

51. Wilson KC, Reardon C, Theodore AC, Farber HW (2005) Propylene glycol toxicity: a severe iatrogenic illness in ICU patients receiving IV benzodiazepines: a case series and prospective, observational pilot study. Chest 128:1674-1681

52. Yahwak JA, Riker RR, Fraser GL, Subak-Sharpe S (2003) An observational pilot study of osmolar gap monitoring to detect propylene glycol toxicity in adult icu patients receiving high-dose lorazepam. CHEST Journal 124:178S-a

53. Shehab N, Lewis CL, Streetman DD, Donn SM (2009) Exposure to the pharmaceutical excipients benzyl alcohol and propylene glycol among critically ill neonates. Pediatr Crit Care Med 10:256-259

54. Kulo A, de Hoon JN, Allegaert K (2012) The propylene glycol research project to illustrate the feasibility and difficulties to study toxicokinetics in neonates. Int J Pharm 435:112-114

55. Allegaert K, Vanhaesebrouck S, Kulo A, Cosaert K, Verbesselt R, Debeer A, de Hoon J (2010) Prospective assessment of short-term propylene glycol tolerance in neonates. Arch Dis Child 95:1054 1058

56. Mullins ME, Barnes BJ (2002) Hyperosmolar metabolic acidosis and intravenous Lorazepam. N Engl J Med 347:857-858, author reply $857-858$ 
57. Jones KL, Arslanian S, Peterokova VA, Park JS, Tomlinson MJ (2002) Effect of metformin in pediatric patients with type 2 diabetes: a randomized controlled trial. Diabetes Care 25:89-94

58. Gaylor AS, Condren ME (2004) Type 2 diabetes mellitus in the pediatric population. Pharmacotherapy $24: 871-878$

59. Kirpichnikov D, McFarlane SI, Sowers JR (2002) Metformin: an update. Ann Intern Med 137:25-33

60. Salpeter SR, Greyber E, Pasternak GA, Salpeter EE (2010) Risk of fatal and nonfatal lactic acidosis with metformin use in type 2 diabetes mellitus. Cochrane Database Syst Rev CD002967

61. Brown JB, Pedula K, Barzilay J, Herson MK, Latare P (1998) Lactic acidosis rates in type 2 diabetes. Diabetes Care 21:1659-1663

62. Misbin RI, Green L, Stadel BV, Gueriguian JL, Gubbi A, Fleming GA (1998) Lactic acidosis in patients with diabetes treated with metformin. N Engl J Med 338:265-266

63. Spiller HA, Weber JA, Winter ML, Klein-Schwartz W, Hofman M, Gorman SE, Stork CM, Krenzelok EP (2000) Multicenter case series of pediatric metformin ingestion. Ann Pharmacother 34: 1385-1388

64. Owen MR, Doran E, Halestrap AP (2000) Evidence that metformin exerts its anti-diabetic effects through inhibition of complex 1 of the mitochondrial respiratory chain. Biochem J 348(Pt 3):607-614

65. El-Mir MY, Nogueira V, Fontaine E, Averet N, Rigoulet M, Leverve X (2000) Dimethylbiguanide inhibits cell respiration via an indirect effect targeted on the respiratory chain complex I. J Biol Chem 275: 223-228

66. Schafer G, Bojanowski D (1972) Interaction of biguanides with mitochondrial and synthetic membranes. Eur J Biochem 27:364 375

67. Seidowsky A, Nseir S, Houdret N, Fourrier F (2009) Metforminassociated lactic acidosis: a prognostic and therapeutic study. Crit Care Med 37:2191-2196

68. Fenves AZ, Kirkpatrick HM 3rd, Patel VV, Sweetman L, Emmett M (2006) Increased anion gap metabolic acidosis as a result of 5oxoproline (pyroglutamic acid): a role for acetaminophen. Clin J Am Soc Nephrol 1:441-447

69. Peter JV, Rogers N, Murty S, Gerace R, Mackay R, Peake SL (2006) An unusual cause of severe metabolic acidosis. Med J Aust 185: 223-225

70. Rolleman EJ, Hoorn EJ, Didden P, Zietse R (2008) Guilty as charged: unmeasured urinary anions in a case of pyroglutamic acidosis. Neth J Med 66:351-353

71. DuBose TD Jr (1997) Hyperkalemic hyperchloremic metabolic acidosis: pathophysiologic insights. Kidney Int 51:591-602

72. Karet FE (2009) Mechanisms in hyperkalemic renal tubular acidosis. J Am Soc Nephrol 20:251-254

73. Wang JL, Cheng HF, Harris RC (1999) Cyclooxygenase-2 inhibition decreases renin content and lowers blood pressure in a model of renovascular hypertension. Hypertension 34:96-101

74. Harris RC, Breyer MD (2006) Update on cyclooxygenase-2 inhibitors. Clin J Am Soc Nephrol 1:236-245

75. O'Kelly R, Magee F, McKenna TJ (1983) Routine heparin therapy inhibits adrenal aldosterone production. J Clin Endocrinol Metab $56: 108-112$

76. Sherman RA, Ruddy MC (1986) Suppression of aldosterone production by low-dose heparin. Am J Nephrol 6:165-168

77. Canova CR, Fischler MP, Reinhart WH (1997) Effect of lowmolecular-weight heparin on serum potassium. Lancet 349:14471448

78. Wiggam MI, Beringer TR (1997) Effect of low-molecularweight heparin on serum concentrations of potassium. Lancet 350:292-293

79. Henger A, Tutt P, Riesen WF, Hulter HN, Krapf R (2000) Acid-base and endocrine effects of aldosterone and angiotensin II inhibition in metabolic acidosis in human patients. J Lab Clin Med 136:379-389
80. Gupta P, Franco-Saenz R, Mulrow PJ (1995) Locally generated angiotensin II in the adrenal gland regulates basal, corticotropin-, and potassium-stimulated aldosterone secretion. Hypertension 25: 443-448

81. Sakemi T, Ohchi N, Sanai T, Rikitake O, Maeda T (1988) Captoprilinduced metabolic acidosis with hyperkalemia. Am J Nephrol 8: 245-248

82. Durand D, Ader JL, Rey JP, Tran-Van T, Lloveras JJ, Bernadet P, Suc JM (1988) Inducing hyperkalemia by converting enzyme inhibitors and heparin. Kidney Int Suppl 25:S196-S197

83. Palmer BF (2011) Metabolic complications associated with use of diuretics. Semin Nephrol 31:542-552

84. DuBose TD Jr, Good DW (1988) Effects of diuretics on renal acidbase transport. Semin Nephrol 8:282-294

85. Wagner CA, Geibel JP (2002) Acid-base transport in the collecting duct. J Nephrol 15(Suppl 5):S112-S127

86. Sastrasinh S, Tannen RL (1983) Effect of potassium on renal NH3 production. Am J Physiol 244:F383-F391

87. Muto S, Tsuruoka S, Miyata Y, Fujimura A, Kusano E (2006) Effect of trimethoprim-sulfamethoxazole on $\mathrm{Na}$ and $\mathrm{K}+$ transport properties in the rabbit cortical collecting duct perfused in vitro. Nephron Physiol 102:51-60

88. Kleyman TR, Roberts C, Ling BN (1995) A mechanism for pentamidine-induced hyperkalemia: inhibition of distal nephron sodium transport. Ann Intern Med 122:103-106

89. Caldas A, Broyer M, Dechaux M, Kleinknecht C (1992) Primary distal tubular acidosis in childhood: clinical study and long-term follow-up of 28 patients. J Pediatr 121:233-241

90. Rodriguez Soriano J (2002) Renal tubular acidosis: the clinical entity. J Am Soc Nephrol 13:2160-2170

91. Sawaya BP, Briggs JP, Schnermann J (1995) Amphotericin B nephrotoxicity: the adverse consequences of altered membrane properties. J Am Soc Nephrol 6:154-164

92. Douglas JB, Healy JK (1969) Nephrotoxic effects of amphotericin $\mathrm{B}$, including renal tubular acidosis. Am J Med 46:154-162

93. Burges JL, Birchall R (1972) Nephrotoxicity of amphotericin B, with emphasis on changes in tubular function. Am J Med 53:77-84

94. Steinmetz PR, Lawson LR (1970) Defect in urinary acidification induced in vitro by amphotericin B. J Clin Invest 49:596-601

95. Stamm AM, Diasio RB, Dismukes WE, Shadomy S, Cloud GA, Bowles CA, Karam GH, Espinel-Ingroff A (1987) Toxicity of amphotericin B plus flucytosine in 194 patients with cryptococcal meningitis. Am J Med 83:236-242

96. Barbour GL, Straub KD, O'Neal BL, Leatherman JW (1979) Vasopressin-resistant nephrogenic diabetes insipidus. A result of amphotericin B therapy. Arch Intern Med 139:86-88

97. Hoorn EJ, Zietse R (2007) Combined renal tubular acidosis and diabetes insipidus in hematological disease. Nat Clin Pract Nephrol 3:171-175

98. Marshall BC, Koch WC (2009) Antivirals for cytomegalovirus infection in neonates and infants: focus on pharmacokinetics, formulations, dosing, and adverse events. Paediatr Drugs 11: 309-321

99. Hatchette T, Tipples GA, Peters G, Alsuwaidi A, Zhou J, Mailman TL (2008) Foscarnet salvage therapy for acyclovir-resistant varicella zoster: report of a novel thymidine kinase mutation and review of the literature. Pediatr Infect Dis J 27:75-77

100. Deray G, Martinez F, Katlama C, Levaltier B, Beaufils H, Danis M, Rozenheim M, Baumelou A, Dohin E, Gentilini M, Jacobs C (1989) Foscarnet nephrotoxicity: mechanism, incidence and prevention. Am J Nephrol 9:316-321

101. Izzedine H, Launay-Vacher V, Deray G (2005) Antiviral druginduced nephrotoxicity. Am J Kidney Dis 45:804-817

102. Navarro JF, Quereda C, Quereda C, Gallego N, Antela A, Mora C, Ortuno J (1996) Nephrogenic diabetes insipidus and renal tubular 
acidosis secondary to foscarnet therapy. Am J Kidney Dis 27:431434

103. Igarashi T, Ishii T, Watanabe $\mathrm{K}$, Hayakawa H, Horio $\mathrm{K}$, Sone $\mathrm{Y}$, Ohga K (1994) Persistent isolated proximal renal tubular acidosis-a systemic disease with a distinct clinical entity. Pediatr Nephrol 8: 70-71

104. Nash MA, Torrado AD, Greifer I, Spitzer A, Edelmann CM Jr (1972) Renal tubular acidosis in infants and children. Clinical course, response to treatment, and prognosis. J Pediatr 80:738-748

105. Hsu SY, Tsai IJ, Tsau YK (2005) Comparison of growth in primary Fanconi syndrome and proximal renal tubular acidosis. Pediatr Nephrol 20:460-464

106. Stohr W, Paulides M, Bielack S, Jurgens H, Treuner J, Rossi R, Langer T, Beck JD (2007) Ifosfamide-induced nephrotoxicity in 593 sarcoma patients: a report from the Late Effects Surveillance System. Pediatr Blood Cancer 48:447-452

107. Pratt CB, Meyer WH, Jenkins JJ, Avery L, McKay CP, Wyatt RJ, Hancock ML (1991) Ifosfamide, Fanconi's syndrome, and rickets. J Clin Oncol 9:1495-1499

108. Rossi R, Pleyer J, Schafers P, Kuhn N, Kleta R, Deufel T, Jurgens H (1999) Development of ifosfamide-induced nephrotoxicity: prospective follow-up in 75 patients. Med Pediatr Oncol 32:177-182

109. Skinner R, Pearson AD, English MW, Price L, Wyllie RA, Coulthard MG, Craft AW (1996) Risk factors for ifosfamide nephrotoxicity in children. Lancet 348:578-580

110. Rodriguez Soriano J, Boichis H, Stark H, Edelmann CM Jr (1967) Proximal renal tubular acidosis. A defect in bicarbonate reabsorption with normal urinary acidification. Pediatr Res 1:81-98

111. Izzedine H, Launay-Vacher V, Isnard-Bagnis C, Deray G (2003) Drug-induced Fanconi's syndrome. Am J Kidney Dis 41:292-309

112. Hall AM, Bass P, Unwin RJ (2014) Drug-induced renal Fanconi syndrome. QJM 107:261-269

113. Haque SK, Ariceta G, Batlle D (2012) Proximal renal tubular acidosis: a not so rare disorder of multiple etiologies. Nephrol Dial Transplant 27:4273-4287

114. Stevens MC, Brandis M (1993) Incidence and etiology of ifosfamide nephrotoxicity: report of a meeting held in Rhodes, Greece, October 3, 1991, sponsored by Asta Medica, Frankfurt, Germany. Med Pediatr Oncol 21:640-644

115. Skinner R, Cotterill SJ, Stevens MC (2000) Risk factors for nephrotoxicity after ifosfamide treatment in children: a UKCCSG Late Effects Group study. United Kingdom Children's Cancer Study Group. Br J Cancer 82:1636-1645

116. Ashraf MS, Skinner R, English MW, Craft AW, Pearson AD (1997) Late reversibility of chronic ifosfamide-associated nephrotoxicity in a child. Med Pediatr Oncol 28:62-64

117. Yaseen Z, Michoudet C, Baverel G, Dubourg L (2008) Mechanisms of the ifosfamide-induced inhibition of endocytosis in the rat proximal kidney tubule. Arch Toxicol 82:607-614

118. Cachat F, Nenadov-Beck M, Guignard JP (1998) Occurrence of an acute Fanconi syndrome following cisplatin chemotherapy. Med Pediatr Oncol 31:40-41

119. Negro A, Grasselli C, Galli P (2010) Oxaliplatin-induced proximal renal tubular acidosis. Intern Emerg Med 5:267-268

120. Linch M, Cunningham D, Mingo O, Stiles A, Farquhar-Smith WP (2007) Renal tubular acidosis due to oxaliplatin. Ann Oncol 18: 805-806

121. Portilla D, Li S, Nagothu KK, Megyesi J, Kaissling B, Schnackenberg L, Safirstein RL, Beger RD (2006) Metabolomic study of cisplatininduced nephrotoxicity. Kidney Int 69:2194-2204

122. Takamoto K, Kawada M, Usui T, Ishizuka M, Ikeda D (2003) Aminoglycoside antibiotics reduce glucose reabsorption in kidney through down-regulation of SGLT1. Biochem Biophys Res Commun 308:866-871

123. Xu EY, Perlina A, Vu H, Troth SP, Brennan RJ, Aslamkhan AG, Xu Q (2008) Integrated pathway analysis of rat urine metabolic profiles and kidney transcriptomic profiles to elucidate the systems toxicology of model nephrotoxicants. Chem Res Toxicol 21:1548-1561

124. Scholl-Burgi S, Santer R, Ehrich JH (2004) Long-term outcome of renal glucosuria type 0 : the original patient and his natural history. Nephrol Dial Transplant 19:2394-2396

125. Santer R, Calado J (2010) Familial renal glucosuria and SGLT2: from a mendelian trait to a therapeutic target. Clin J Am Soc Nephrol 5:133-141

126. Karlmark B, Agerup B, Wistrand PJ (1979) Renal proximal tubular acidification. Role of brush-border and cytoplasmic carbonic anhydrase. Acta Physiol Scand 106:145-150

127. Schwartz GJ (2002) Physiology and molecular biology of renal carbonic anhydrase. J Nephrol 15(Suppl 5):S61-S74

128. Winum JY, Poulsen SA, Supuran CT (2009) Therapeutic applications of glycosidic carbonic anhydrase inhibitors. Med Res Rev 29: $419-435$

129. Tsuruoka S, Schwartz GJ (1998) HCO3- absorption in rabbit outer medullary collecting duct: role of luminal carbonic anhydrase. Am J Physiol 274:F139-F147

130. World Health Organization (2012) Global epidemic and health care response. In: Global summary of the HIV/AIDS epidemic

131. World Health Organization (2012) Technical update on treatment optimization: use of tenofovir disoproxil fumarate in HIV-infected children and adolescents aged $2-18$ years: a public health perspective. WHO HIV/AIDS Programme

132. Gupta SK (2008) Tenofovir-associated Fanconi syndrome: review of the FDA adverse event reporting system. AIDS Patient Care STDS 22:99-103

133. Hall AM, Hendry BM, Nitsch D, Connolly JO (2011) Tenofovirassociated kidney toxicity in HIV-infected patients: a review of the evidence. Am J Kidney Dis 57:773-780

134. Imaoka $\mathrm{T}$, Kusuhara $\mathrm{H}$, Adachi M, Schuetz JD, Takeuchi K, Sugiyama Y (2007) Functional involvement of multidrug resistance-associated protein 4 (MRP4/ABCC4) in the renal elimination of the antiviral drugs adefovir and tenofovir. Mol Pharmacol 71: 619-627

135. Hall AM (2013) Update on tenofovir toxicity in the kidney. Pediatr Nephrol 28:1011-1023

136. Liborio AB, Andrade L, Pereira LV, Sanches TR, Shimizu MH, Seguro AC (2008) Rosiglitazone reverses tenofovir-induced nephrotoxicity. Kidney Int 74:910-918

137. Endo A, Fujita Y, Fuchigami T, Takahashi S, Mugishima H (2010) Fanconi syndrome caused by valproic acid. Pediatr Neurol 42:287290

138. Watanabe T, Yoshikawa H, Yamazaki S, Abe Y, Abe T (2005) Secondary renal Fanconi syndrome caused by valproate therapy. Pediatr Nephrol 20:814-817

139. Yoshikawa H, Watanabe T, Abe T (2002) Fanconi syndrome caused by sodium valproate: report of three severely disabled children. Eur J Paediatr Neurol 6:165-167

140. Knorr M, Schaper J, Harjes M, Mayatepek E, Rosenbaum T (2004) Fanconi syndrome caused by antiepileptic therapy with valproic Acid. Epilepsia 45:868-871

141. Hawkins E, Brewer E (1993) Renal toxicity induced by valproic acid (Depakene). Pediatr Pathol 13:863-868

142. Lenoir GR, Perignon JL, Gubler MC, Broyer M (1981) Valproic acid: a possible cause of proximal tubular renal syndrome. J Pediatr 98:503-504

143. Alexandridis G, Liberopoulos E, Elisaf M (2003) Aminoglycosideinduced reversible tubular dysfunction. Pharmacology 67:118-120

144. Bennett WM, Mela-Riker LM, Houghton DC, Gilbert DN, Buss WC (1988) Microsomal protein synthesis inhibition: an early manifestation of gentamicin nephrotoxicity. Am J Physiol 255:F265F269

145. Weinberg JM, Harding PG, Humes HD (1980) Mechanisms of gentamicin-induced dysfunction of renal cortical mitochondria. II. 
Effects on mitochondrial monovalent cation transport. Arch Biochem Biophys 205:232-239

146. Sassen MC, Kim SW, Kwon TH, Knepper MA, Miller RT, Frokiaer J, Nielsen S (2006) Dysregulation of renal sodium transporters in gentamicin-treated rats. Kidney Int 70:1026-1037

147. Hemstreet BA (2004) Antimicrobial-associated renal tubular acidosis. Ann Pharmacother 38:1031-1038

148. Babu E, Takeda M, Narikawa S, Kobayashi Y, Yamamoto T, Cha SH, Sekine T, Sakthisekaran D, Endou H (2002) Human organic anion transporters mediate the transport of tetracycline. Jpn J Pharmacol 88:69-76

149. Connell SR, Tracz DM, Nierhaus KH, Taylor DE (2003) Ribosomal protection proteins and their mechanism of tetracycline resistance. Antimicrob Agents Chemother 47:3675-3681

150. Wirmer J, Westhof E (2006) Molecular contacts between antibiotics and the 30S ribosomal particle. Methods Enzymol 415:180-202

151. Anderson LE, Henrich WL (1987) Alkalemia-associated morbidity and mortality in medical and surgical patients. South Med J 80:729733

152. Wilson RF, Gibson D, Percinel AK, Ali MA, Baker G, LeBlanc LP, Lucas C (1972) Severe alkalosis in critically ill surgical patients. Arch Surg 105:197-203

153. Webster NR, Kulkarni V (1999) Metabolic alkalosis in the critically ill. Crit Rev Clin Lab Sci 36:497-510

154. Leusen I (1950) Blood $\mathrm{pH}$, cerebrospinal fluid $\mathrm{pH}$ and the respiratory function. Arch Int Physiol 58:115-116

155. Brimioulle S, Kahn RJ (1990) Effects of metabolic alkalosis on pulmonary gas exchange. Am Rev Respir Dis 141:1185-1189

156. Bellingham AJ, Detter JC, Lenfant C (1971) Regulatory mechanisms of hemoglobin oxygen affinity in acidosis and alkalosis. $\mathrm{J}$ Clin Invest 50:700-706

157. Yasue H, Omote S, Takizawa A, Nagao M, Nosaka K, Nakajima H (1981) Alkalosis-induced coronary vasoconstriction: effects of calcium, diltiazem, nitroglycerin, and propranolol. Am Heart J 102: 206-210

158. Loon NR, Wilcox CS (1998) Mild metabolic alkalosis impairs the natriuretic response to bumetanide in normal human subjects. Clin Sci (Lond) 94:287-292

159. Sica DA (2004) Diuretic-related side effects: development and treatment. J Clin Hypertens (Greenwich) 6:532-540

160. Cannon PJ, Heinemann HO, Albert MS, Laragh JH, Winters RW (1965) "Contraction" Alkalosis after Diuresis of Edematous Patients with Ethacrynic Acid. Ann Intern Med 62:979-990

161. Schwartz WB, Cohen JJ (1978) The nature of the renal response to chronic disorders of acid-base equilibrium. Am J Med 64:417-428

162. Cohen JJ (1968) Correction of metabolic alkalosis by the kidney after isomertric expansion of extracellular fluid. J Clin Invest 47: $1181-1192$

163. Luke RG, Galla JH (2012) It is chloride depletion alkalosis, not contraction alkalosis. J Am Soc Nephrol 23:204-207

164. Galla JH, Bonduris DN, Luke RG (1987) Effects of chloride and extracellular fluid volume on bicarbonate reabsorption along the nephron in metabolic alkalosis in the rat. Reassessment of the classical hypothesis of the pathogenesis of metabolic alkalosis. J Clin Invest 80:41-50

165. Brunner FP, Frick PG (1968) Hypokalaemia, metabolic alkalosis, and hypernatraemia due to "massive" sodium penicillin therapy. $\mathrm{Br}$ Med J 4:550-552

166. Lipner HI, Ruzany F, Dasgupta M, Lief PD, Bank N (1975) The behavior of carbenicillin as a nonreabsorbable anion. J Lab Clin Med 86:183-194

167. Hoorn EJ, Zietse R (2008) Severe hypokalaemia caused by flucloxacillin. J Antimicrob Chemother 61:1396-1398
168. Ward DT, McLarnon SJ, Riccardi D (2002) Aminoglycosides increase intracellular calcium levels and ERK activity in proximal tubular OK cells expressing the extracellular calcium-sensing receptor. J Am Soc Nephrol 13:1481-1489

169. Ward DT, Maldonado-Perez D, Hollins L, Riccardi D (2005) Aminoglycosides induce acute cell signaling and chronic cell death in renal cells that express the calcium-sensing receptor. J Am Soc Nephrol 16:1236-1244

170. McLarnon S, Holden D, Ward D, Jones M, Elliott A, Riccardi D (2002) Aminoglycoside antibiotics induce $\mathrm{pH}$-sensitive activation of the calcium-sensing receptor. Biochem Biophys Res Commun 297:71-77

171. Riccardi D, Hall AE, Chattopadhyay N, Xu JZ, Brown EM, Hebert SC (1998) Localization of the extracellular Ca2+/polyvalent cationsensing protein in rat kidney. Am J Physiol 274:F611-F622

172. Shiah CJ, Tsai DM, Liao ST, Siauw CP, Lee LS (1994) Acute muscular paralysis in an adult with subclinical Bartter's syndrome associated with gentamicin administration. Am J Kidney Dis 24: 932-935

173. Szylman P, Better OS, Chaimowitz C, Rosler A (1976) Role of hyperkalemia in the metabolic acidosis of isolated hypoaldosteronism. N Engl J Med 294:361-365

174. Finton CK, Bjorkland S, Zaloga GP, Uddin DE, Chernow B (1983) Gentamicin-induced hypomagnesemia. Am Surg 49:576-578

175. Elliott C, Newman N, Madan A (2000) Gentamicin effects on urinary electrolyte excretion in healthy subjects. Clin Pharmacol Ther 67:16-21

176. Muller-Lissner SA (1993) Adverse effects of laxatives: fact and fiction. Pharmacology 47(Suppl 1):138-145

177. Eldridge DL, Van Eyk J, Kornegay C (2007) Pediatric toxicology. Emerg Med Clin North Am 25:283-308, abstract vii-viii

178. Beall DP, Henslee HB, Webb HR, Scofield RH (2006) Milk-alkali syndrome: a historical review and description of the modern version of the syndrome. Am J Med Sci 331:233-242

179. Patel AM, Goldfarb S (2010) Got calcium? Welcome to the calcium-alkali syndrome. J Am Soc Nephrol 21:1440-1443

180. Wagner CL, Greer FR (2008) Prevention of rickets and vitamin D deficiency in infants, children, and adolescents. Pediatrics 122: $1142-1152$

181. Vanstone MB, Oberfield SE, Shader L, Ardeshirpour L, Carpenter TO (2012) Hypercalcemia in children receiving pharmacologic doses of vitamin D. Pediatrics 129:e1060-e1063

182. Medarov BI (2009) Milk-alkali syndrome. Mayo Clin Proc 84:261267

183. Felsenfeld AJ, Levine BS (2006) Milk alkali syndrome and the dynamics of calcium homeostasis. Clin J Am Soc Nephrol 1:641654

184. Arroliga AC, Shehab N, McCarthy K, Gonzales JP (2004) Relationship of continuous infusion lorazepam to serum propylene glycol concentration in critically ill adults. Crit Care Med 32:17091714

185. Zietse R, Zoutendijk R, Hoorn EJ (2009) Fluid, electrolyte and acid-base disorders associated with antibiotic therapy. Nat Rev Nephrol 5:193-202

186. Galla JH, Rome L, Luke RG (1995) Bicarbonate transport in collecting duct segments during chloride-depletion alkalosis. Kidney Int 48:52-55

Correct answers:

$1 \mathrm{a}, 2 \mathrm{~b}, 3 \mathrm{c}, 4 \mathrm{~b}, 5 \mathrm{~d}$ 